\title{
Architecture of Solar Energy
}

appropriating photovoltaic technology for the design of sustainable buildings

by

\author{
Gandhi Habash
}

\begin{abstract}
A thesis submitted to the Faculty of Graduate and Postdoctoral Affairs in partial fulfillment of the requirements for the degree of
\end{abstract}

\section{Master of Architecture}

\author{
Carleton University \\ Ottawa, Ontario
}

(C) 2017

Gandhi Habash 


\section{Abstract}

Renewable energy is part of a $21^{\text {st }}$ century sustainability paradigm that responds to environmental degradation, forming western society's existential concern for earth- often referred to as the 'green' movement. New tools and technologies, both for building design and construction, have come to assist architects in the creation of buildings that produce their own energy and which consume less of it. Renewable energy production strategies are necessary in order to mitigate the issue of future energy security, as traditional sources of fuel become increasingly scarce. This thesis presents a proposal for a building that can produce power by incorporating a photovoltaic and thermal energy collection system as a programmed design component, offering an architectural solution to what is traditionally viewed as an engineering problem. From this perspective renewable energy systems can be integrated as both functional and aesthetic elements within buildings. 


\section{Acknowledgments}

I would like to thank my advisor Stephen Fai for his guidance and direction throughout the development of this thesis, and Scott Bucking for his insight in the area of building integrated photovoltaics.

I am also grateful for the encouragement of my classmates and coworkers, many of whom have become lifelong friends during this journey.

And finally, to my parents Riadh and Najat: your unfading interest in, and support of, my passion for architecture has been the greatest inspiration of all. 


\section{Contents}

Abstract II

Acknowledgments III

Table of contents IV

List of figures $\quad \mathrm{V}$

List of tables $\quad$ VI

List of acronyms and definitions VII

1 Introduction 11

1.1 Sustainability ............................................................................ 11

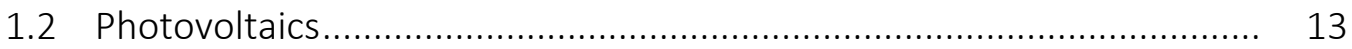

2 Literature Review $\quad 17$

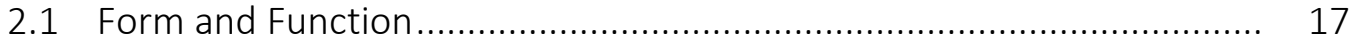

2.2 Effects of Heat on Performance ........................................................ 18

2.2.1 Double Skin Facades .............................................................. 19

2.3 Adaptive Facades ................................................................... 20

2.4 Building Precedents ..................................................................... 21

3 Methodology 26

3.1 Site Selection and Building Program.............................................. 26

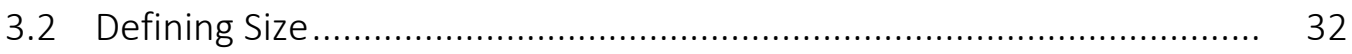

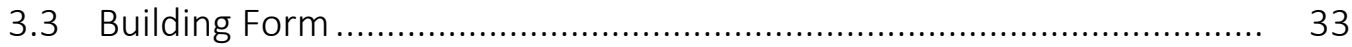


3.3.1 Optimization for Energy Capture.............................................. 33

3.3.2 Building Plan and Section .................................................. 37

3.3.3 Incorporation of Passive Strategies ......................................... 42

3.3.4 Estimating Electricity Generation Potential ........................... 48

4 Conclusions and Recommendations 50

4.1 Technical Challenges.................................................................... 51

4.2 Design Challenges ............................................................................ 51

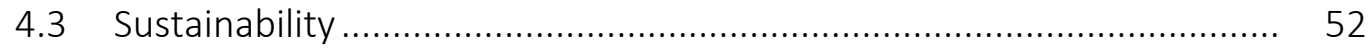

Bibliography $\quad 54$ 


\section{List of Figures}

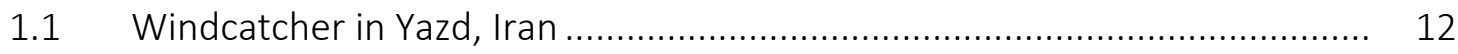

1.2 Diagram showing components of a Photovoltaic Array ................................ 13

1.3 Traditional Methods of Integrating PV Systems ......................................... 14

2.1 Annual Sum of Irradiation by Geographic Area .......................................... 17

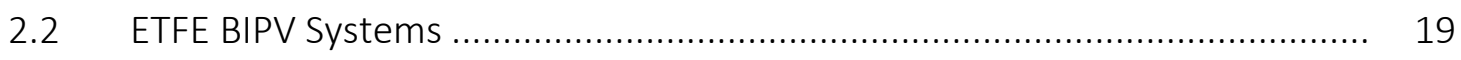

2.3 Ventilated BIPV Cavity Wall Systems ....................................................... 20

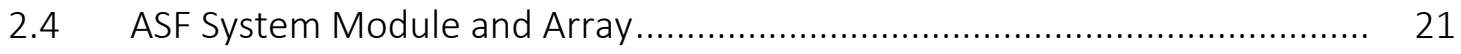

2.5 BIPV Façade and Skylight on a Skyscraper in Seoul, South Korea .................. 22

2.6 Low Energy Office Building in Aarhus, Denmark …………………............ 23

2.7 Office Building for a Law Firm in Copenhagen, Denmark ............................. 23

2.8 Faceted BIPV/shading system ............................................................ 24

2.9 ETFE BIPV Façade on the U.S. Chancery in London, United Kingdom ........... 25

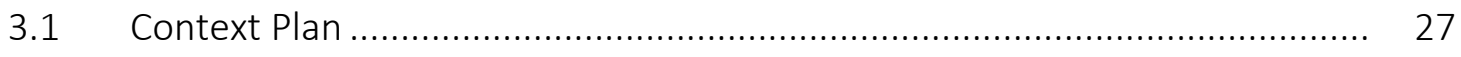

3.2 Rendezvous Lebreton Group's Winning Proposal for Lebreton Flats' 28 Masterplanning

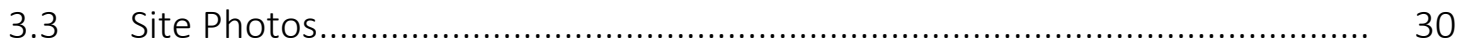


3.4 45 Parliament Street Data Centre ....................................................... 30

3.5 Functional Program of a Typical Data Centre ............................................ 31

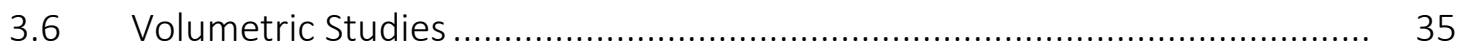

3.7 Volumetric Studies - Sawtooth Facade ................................................ 35

3.8 Aerial Perspective of Proposed Building ............................................ 36

3.9 Southeast Elevation of Proposed Building .......................................... 36

3.10 Perspective Showing the Interior Lobby Space ..................................... 38

3.11 Perspective Showing the Proposed Building in Context ............................ 39

3.12 Sections Through Proposed Building ............................................. 39

3.13 Plans of Proposed Building................................................................... 40

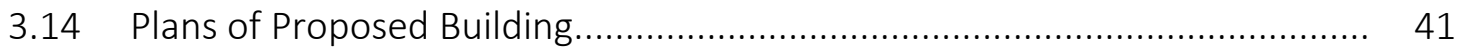

3.15 Prevailing Winds in the Ottawa Region During 2013 .............................. 42

3.16 Section Perspective showing Multiple-Inlet System .............................. 43

3.17 Exterior Perspective showing Multiple-Inlet System............................... 44

3.18 Exterior Perspective showing Multiple-Inlet System............................... 45

3.19 Exterior Perspective showing Multiple-Inlet System................................ 46

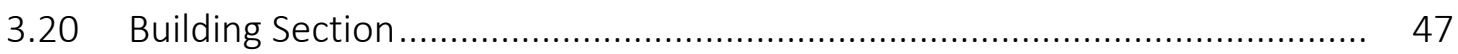

3.21 Plan Highlighting Surfaces Exposed to Varying Levels of Irradiation ............ 48 


\section{List of Tables}

3.1 Cabinet Power Density and Heat Load.................................................. 32

3.2 Size and Capacity of Various Canadian Data Centres ................................... 33

3.3 Orientation for Maximum Annual Energy Production in 10 Canadian Cities... 34

3.4 Yearly PV Potential of Major Canadian Cities and Cities Worldwide............... 49 


\title{
List of Acronyms and Definitions
}

\author{
Acronyms \\ AC \\ Alternating Current \\ ASF Adaptive Solar Facade \\ ASHRAE American Society of Heating, Refrigerating and Air-Conditioning \\ Engineers \\ a-Si Amorphous Silicon Photovoltaic Cell \\ BIPV Building Integrated Photovoltaics \\ c-Si Crystalline Silicon Photovoltaic Cell \\ DC Direct Current \\ DHW District Hot Water System \\ ETFE Ethylene Tetrafluoroethylene \\ HVAC Heating, Ventilation and Air Conditioning \\ NCC National Capital Commission \\ NRCAN Natural Resources Canada \\ OPV Organic Photovoltaic Cell \\ OJVF Open Joint Ventilated Facade \\ PV Photovoltaics \\ VCS Ventilated Core Slab
}




\section{Definitions}

Capacity the ratio of actual electrical energy output over a given period of time

Factor to the maximum possible electrical energy output over the same period

Insolation solar radiation that reaches the Earth's surface

Irradiance the radiant flux (power) received received by a surface per unit area

Temperature figure that represents the power output loss of a photovoltaic cell for Coefficient every ${ }^{\circ} \mathrm{C}$ increase in surface temperature; figure is unique to each type of PV cell 


\section{Introduction}

\subsection{Sustainability}

Technological advances in the global age have transformed previously local economies into an international consumer culture. Governments rely on the employment and services associated with both upstream and downstream economies in order for their social systems to remain viable (Harris, 535-538), hurtling societies toward crisis levels of overpopulation and pollution. Consumerism as a dominant global social force has increased pollution, necessitating the invention of various means by which to manage its quantifiable environmental impact. Since buildings are the greatest consumers of energy, architects have been tasked with generating solutions for more resource and energy efficient designs at all scales. Naturally, this calls into question what such typologies ought to look like, or whether their sustainable quality can or should be visually expressed at all. For centuries prior to the invention of modern building climate control systems, substantial architectural elements such as wind catchers (figure 1.1) were used to ventilate and cool buildings in hot and arid or humid areas. Such technologies are still used today in parts of the Middle East and North Africa, and similar solutions have been integrated into net-zero and net-positive buildings throughout Canada. New technologies are often designed and integrated alongside historic ones to create novel solutions for age-old problems, as well as for emerging ones. 

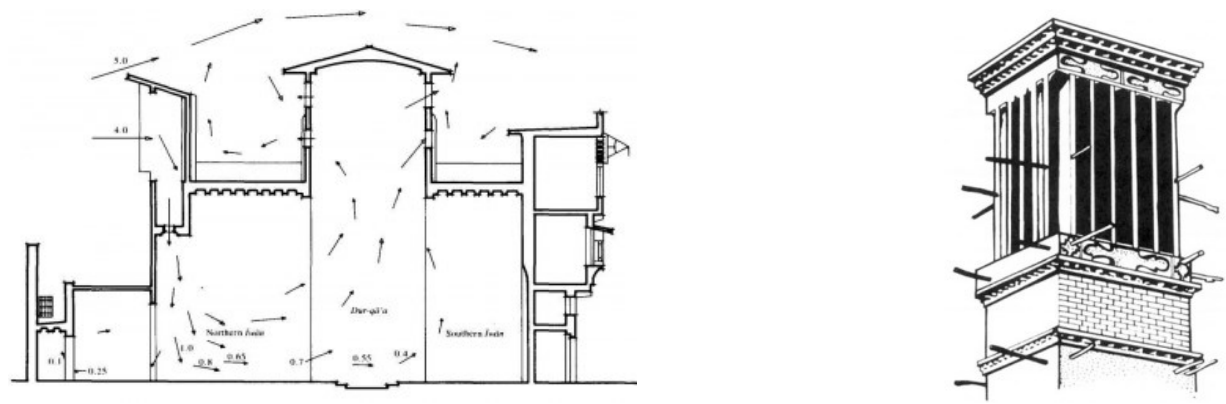

Source: Dehghani-Sanij, A.r., M. Soltani, and K. Raahemifar. "A New Design of Wind Tower for Passive Ventilation in Buildings to Reduce Energy Consumption in Windy Regions." Renewable and Sustainable Energy Reviews 42 (2015): 18295. Web.

Figure 1.1: (left) basic airflow through a windcatcher; (right) windcatcher in Yazd, Iran

When it comes to the power of the sun, mankind has always sought to harness its energy for everyday needs. It has been an important resource and challenge for designers, faced with balancing natural lighting with the risk of overheating. Passive solar design seeks to reduce the energy consumption of buildings as well as produce ones that act in conjunction with natural forces, not against them. Active solar energy systems are a relatively new area in architecture; building-integrated photovoltaic (BIPV) electric power systems are a major new technology in current practice, particularly as they relate to energy performance. Such systems have become more sophisticated and not only produce electricity, but can also be substantial functional and decorative building elements. The design and performance potential of BIPV systems are being taken more seriously as the technology becomes cheaper and more efficient. For example, a BIPV double-skin facade is an integral component of the building envelope as well as a solar electric energy system that generates power, preheats ventilation air, and protects from sound, wind, and pollutants which make life in urban areas less comfortable. Such systems are therefore multifunctional construction materials with both passive and active elements.

Woodrow W. Clark II highlights the Green Industrial Revolution in his book, Global Energy Innovation. He remarks on how it is about more than just renewable energy systems and storage technologies, noting that such systems have to be "combined and integrated in order to be more conversational and efficient as well as reducing the carbon and emissions in the global atmosphere." It is in such a context that architects must incorporate 
appropriate technologies like photovoltaics into the design of their buildings, yet not ignore the merits of historic precedents. New technologies should enhance and not replace or obfuscate pre-existing ones.

\subsection{Photovoltaics}

The standard element of a BIPV system is the photovoltaic (PV) module, composed of individual solar cells. These are strung together with cables and wires to form a PV array (figure 1.2). Direct or diffuse sunlight shining on the cells induces the photovoltaic effect, generating unregulated DC electric power. DC power can be used directly, stored into a battery system, or fed into an inverter that transforms and synchronizes the power into AC electricity. The electricity can be used within the building or exported to a utility company through a grid interconnection.

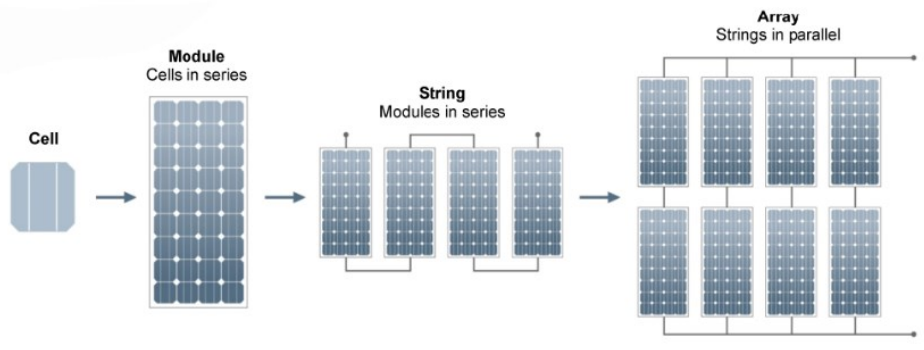

Source: www.pure-eie.com

Figure 1.2: diagram showing components of a photovoltaic array

There are four main types of photovoltaic cells that are commercially available: amorphous silicon (a-Si); monocrystalline silicon (c-Si); polycrystalline silicon (c-Si); and hybrid cells. aSi cells are flexible and are more efficient under higher temperatures due to annealing effects, while overall they are less efficient (6-8\%) and costlier than both types of crystalline silicon cells. a-Si, in contrast to c-Si solar cells, are more environmentally friendly as they do not contain toxic heavy metals such as cadmium or lead. The choice of material depends on the architectural solution for an application. Whereas a-Si cells are flexible and can be applied to a variety of geometries, crystalline cells are rigid and have to be installed as faceted components. The trade-off is that c-Si cells are almost twice as efficient as a-Si cells (13-16\%). An alternative type of thin film product is the organic photovoltaic cell (OPV). 
With efficiencies as high as $22 \%$, they are competitive in performance with traditional crystalline cells, with the benefit of being highly flexible, extremely thin, and uniform in appearance. Organic cells also have the potential of being inexpensive to manufacture, however the technology is still relatively young and not yet commercially available; presently organic cells have a much shorter operational lifespan than inorganic (silicon) products (Lin et al. 133-56).

Photovoltaic systems can be integrated into buildings in three ways. The most common method is to simply add commercially available modules onto exterior surfaces; this is often the case in retrofit projects where photovoltaic panels are laid out on commercial rooftops or on the sloped roofs of single family homes. The second method involves the integration of the same commercially available modules within building surfaces; in such cases, the photovoltaic panels can act as both a weather barrier as well as an active energy production component. The third and most fully integrated solution involves making the modules into building components. An example of this type of solution are the solar glass shingles introduced by Tesla in 2016. Tesla's product directly addresses the issue of aesthetics, camouflaging the actual solar cell when viewed from acute angles (e.g. as an onlooker on ground level); the solar cell itself is only visible at perpendicular angles (when viewed directly overhead). All three of these methods (figure 1.3) face the same design and performance challenges.
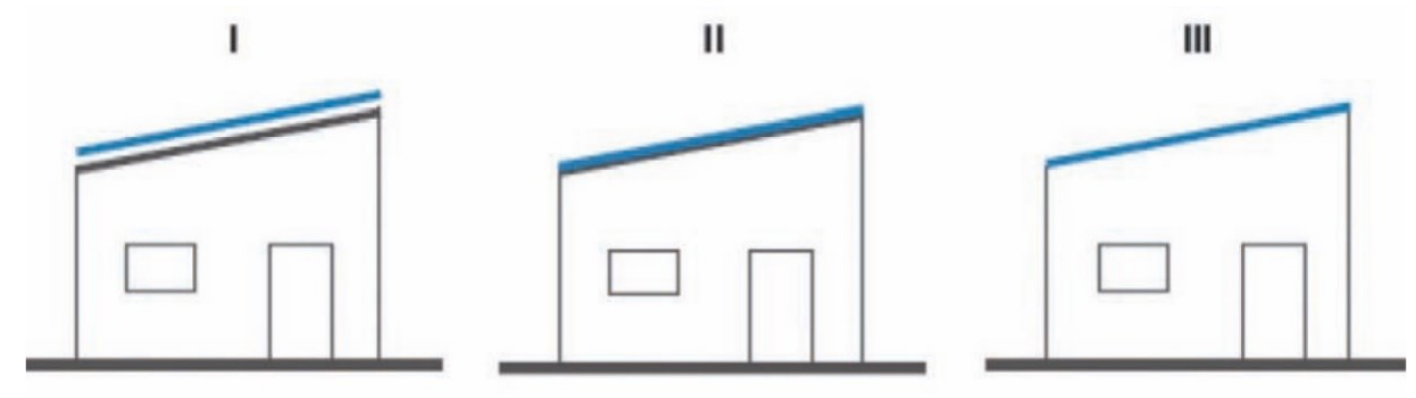

Source: www. pure-eie.com

Figure 1.3: traditional methods of integrating PV systems 
Varieties of BIPV systems are available, however most can be grouped into two primary categories: roof and façade systems. Façade systems include curtain wall products, spandrel panels and individual glazing units. Roof systems include tiles, shingles and skylights. Aside from ready-made commercial products, PV modules can also be designed as aesthetically integrated building components as well as entire structures. When compared with large scale PV solar farms, BIPV can sometimes be the optimal method of installing renewable energy systems, particularly in areas where undeveloped land is scarce, expensive, or inaccessible.

This thesis does not necessarily propose a fourth method of integration, but rather considers issues beyond the technology itself in order to enhance a potential project of architecture. This goes beyond existing methods that are almost always an engineering solution, merely a direct application of existing technology. From an architectural perspective, designs have to be naturally integrated, visually exceptional, and more desirable when compared with existing ones. Renewable technologies cannot appear as though they were put together from a 'kit of parts.' A novel approach is necessary in order for photovoltaics to be successfully integrated into buildings. They can only be included in projects if architects have sufficient knowledge about the technology and have access to appropriate design tools to assist them. Based on these requirements, architects have to approach building design completely differently than in traditional practice.

Picon states that we "still bear the imprint of modernist prejudices," in the sense that modern architects generally tend to dismiss the performativity of décor, as it seems less important than structural or energetic behaviour. When considering buildings that incorporate sustainable technologies and construction methods, their design is not strictly a question of performance or aesthetics. As Picon suggests, the visual expression of ornament is often fundamental to the performance of such buildings, and also serves to describe their purpose. As argued in section 3, an architecture of solar energy is both about the visual expression of technology as well as the development of a novel typology that 
exists solely due to internal and external factors that originated during the late $20^{\text {th }}$ and early $21^{\text {st }}$ centuries. The project of architecture discussed in this section will help define how one may approach the design of such a typology. As the incorporation of such technologies becomes more commonplace, researchers, manufacturers, service providers, and fabricators will take solar technology more seriously as a proper building material, catalyzing further development in the area. 


\section{Literature Review}

\subsection{Form and Function}

Irradiation is the single most important factor affecting PV performance, determined by the local climate and site location (figure 2.1) as well as by the array's surface tilt and orientation. Maximum annual performance of grid-connected PV generators is obtained with modules tilted at an angle equal to the site latitude, facing the equator. The total solar radiation availability directly affects the PV generator's annual energy yield.

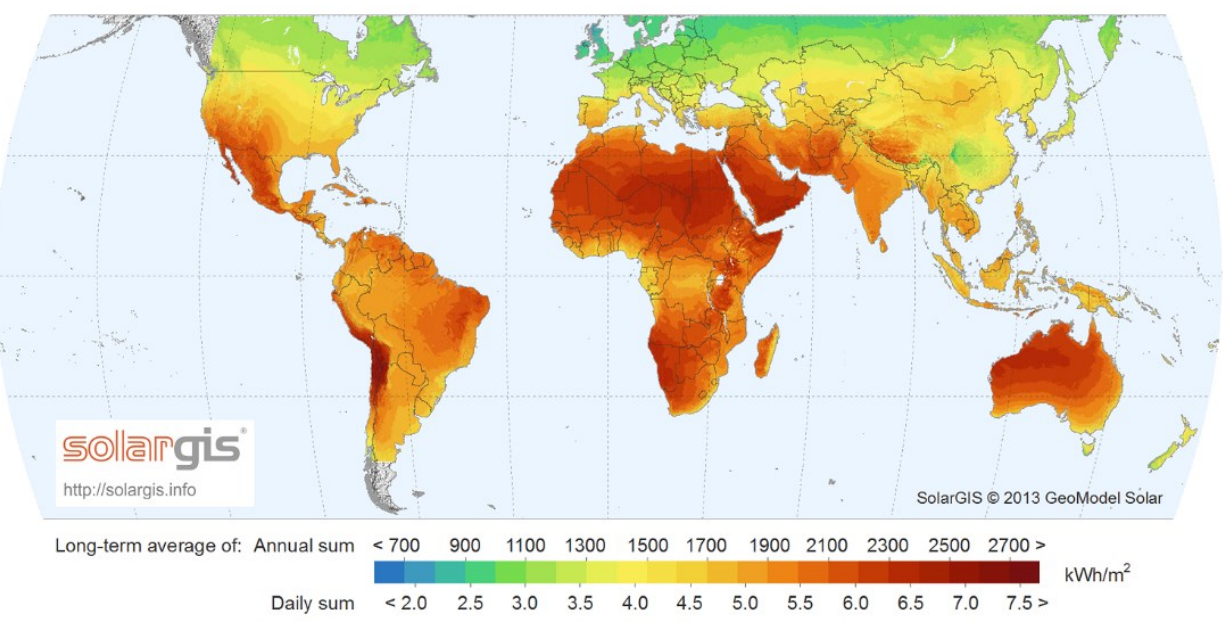

Source: SolarGIS

Figure 2.1: global map showing annual sum of irradiation by geographic area

When all photovoltaic modules are on the same plane, estimating their annual energy production ( $\mathrm{kWh} / \mathrm{kWp} /$ year) can be highly accurate. Estimation becomes more difficult as BIPV systems become increasingly accepted by architects and builders, since irregular and 
curved shapes will be desired. Partial shading as a result of complex geometry is a design issue which can lead to performance losses. Urbanetz et al. found that a curved PV array on a parking shade structure was $10 \%$ less efficient than a flat rooftop array on the same site, due to shading. Consequently, compromises between the aesthetics (form) and energy production (function) expected from a BIPV system will have to be reached. In the case of Urbanetz et al., a 10\% loss can be considered acceptable since the curved design is more visually and functionally appealing for the desired application.

\subsection{Effects of Heat on Performance}

Solar irradiation is more critical in determining the maximum temperature of PV modules than the outdoor air temperature. Depending on the material of PV cells, efficiency reduction due to overheating can be partially alleviated through the integration of a thermal collection system. Such systems absorb much of the heat gained by PV panels through a heat transfer fluid in an open-loop (air) or closed loop (liquid) configuration. The benefits are twofold: collecting more energy and lowering the temperature of PV modules. In such situations, BIPV/T systems are more cost effective (Chen et al. 1894-1895). The collected heat can be used for space heating or district hot water (DHW) heating either by direct means or through a heat pump. Chen et al. incorporated a ventilated core slab (VCS) in the basement of a single family dwelling, utilizing the collected heat as means to warm the hollow-core slab. Chen et al. also found that wind has the most significant cooling effect, whereas mechanical ventilation had a negligible effect; for every $1 \mathrm{~km} / \mathrm{h}$ increase in wind speed, the temperature in the air cavity was reduced by 2 degrees due to convective heat transfer.

While higher temperatures generally result in the reduced performance of PV modules, aSi cells perform more optimally under higher temperatures due to the annealing effect of the material (Hu et al. 50). Amorphous silicon cells offer the added benefit of flexibility and can be integrated into the design of curved geometries, like those of ETFE cushion systems. ETFE BIPV systems also offer the potential to harvest thermal energy between the top and 
bottom layers (within the air cavity), while producing energy and offering ample daylight to the contained spaces. The Japanese Pavilion at Expo 2010 (figure 2.2, left) incorporates a-Si modules on its cushions' extreme outer surfaces. Such applications are not ideal since high temperatures affect the inflation of the skin, compromising the overall structure. Experiments conducted on a full-scale testbed in China show that integrating photovoltaic cells on an intermediate layer mitigates the temperature effects on the structure (Hu et al. $42-45)$.
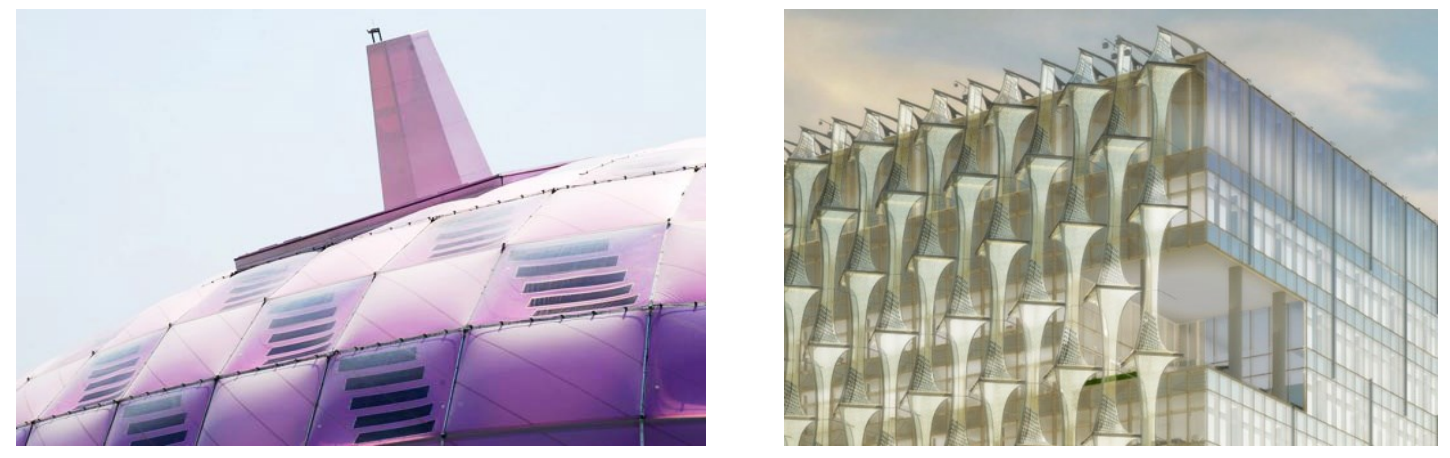

Source: (left) www.inhabitat.com; (right) Kieran Timberlake Architects. United States Chancery, London. 2017. Artist's Concept. US Department of State. Washington, DC.

Figure 2.2: (left) ETFE BIPV system with a-Si PV cells applied to extreme inner surface; (right) façade integrated ETFE BIPV system using crystalline PV cells

\subsubsection{Double Skin Facades}

Double skin ventilated facades offer interesting potential in both the design and performance of BIPV systems: its thermal buffer zone reduces the cooling load during summer months, preventing heat from entering directly through the building envelope; during winter months, the system can be used to preheat ventilation air, thereby reducing the heating load (Agathokelous et al. 745-746). The captured thermal energy can also be exhausted and/or circulated, drawing colder air up the wall assembly- particularly useful for cooling photovoltaic panels since PV efficiency is reduced under high temperatures.

There are two types of ventilated facades; a traditionally ventilated air chamber is only open to the exterior at the top and bottom (figure 2.3, left), while open joint ventilated facades (OJVF) incorporate a series of thin gaps that allow exterior air to enter and exit the 
cavity along the wall or roof assembly (figure 2.3 , right). OJVFs are desirable in climates with hot summers and mild winters, since surface temperatures are higher.
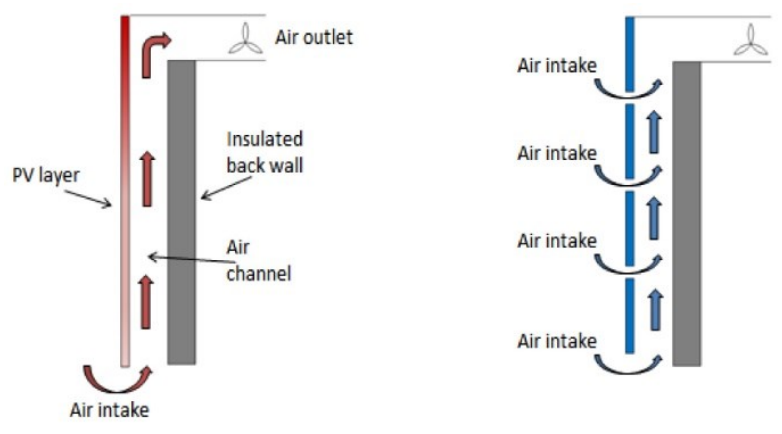

Source: eSim conference paper

Figure 2.3: (left) single inlet BIPV/T system; (right) multiple inlet BIPV/T system

Recent studies have also analyzed OJVF performance in cold climates. Yang et al. showed that a multiple cavity wall assembly increases the thermal efficiency of a BIPV/T system in a cold climate by up to $7 \%$ when compared to a single cavity system. By countering the effect of temperature stratification, the heat within the cavity is evenly distributed and therefore minimizes temperature variation among the PV panels; this facilitates the estimation of energy production. Moreover, a uniform and reduced temperature slows the degradation of PV modules, extending their operational lifespan. From an architectural perspective, the size and location of the air gaps, along with the length and shape of PV panels, has a direct effect on the air collection rate within the cavity, and ultimately system design and performance.

\subsection{Adaptive Facades}

Adaptive Solar Facades (ASF) are modular, dynamic building facades. The basic element of the ASF is a dynamic, multifunctional module which can act autonomously or in a cluster (figure 2.4). Each module is essentially a miniaturized solar tracker. Dynamic facades have the potential to increase the efficiency of BIPV systems by as much as 10 to $25 \%$ (depending on geographic location and design) since individual modules can be raised and twisted in order to maximize direct exposure to solar radiation. Furthermore, they can add 
to the architectural expression of a building. While ASFs are a novel solution to optimize panel orientation, they also pose several challenges, particularly in northern climates. Aside from being slightly more expensive than fixed systems, their more complex technology, consisting of several moving parts, can affect the reliability of their operation. During winter, icing on the actuators can completely inhibit the system's functionality. Costs associated with de-icing and regular maintenance can erase much of the financial value gained from the system's increased energy production.
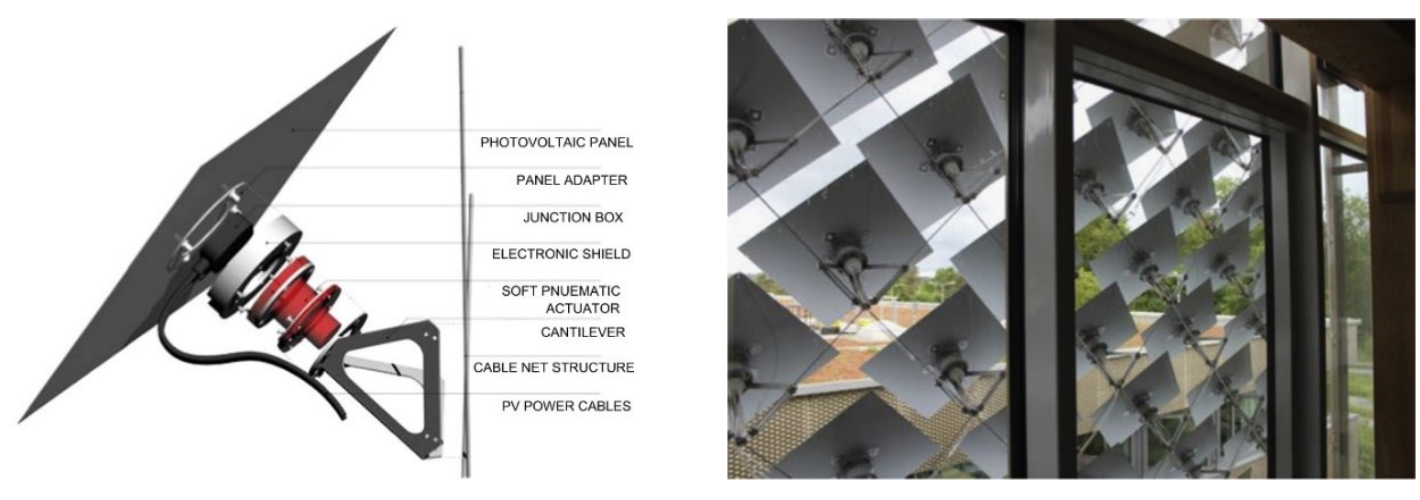

Source: eSim conference paper

Figure 2.4: (left) individual module for an ASF system; (right) an array as part of an ASF system

\subsection{Building Precedents}

Most built examples of façade-integrated photovoltaic systems simply replace vision or spandrel glass with PV modules (figures $2.5,2.6$ ). These designs rely on the respective buildings' large vertical surface area to help compensate for a reduced power output, a result of less than optimal orientation. Given the relatively low efficiency of PV systems (between 15-20\%), especially when considering the loss in DC to AC conversion (10\% of the total system loss), it is not good practice to attribute a loss of output to poor design. Photovoltaics are often implemented in such a manner because the solution employs standardized PV modules of nominal size. PV modules exist in a typically flat and rectangular form factor because it offers an efficiency in their manufacture, reducing cost. While this reason is valid from a basic economic perspective, it limits the design potential available to architects, as well as the performance potential in building projects that do not 
lend themselves to a straightforward application of such solutions, particularly when aesthetics are valued and site conditions are constrained.
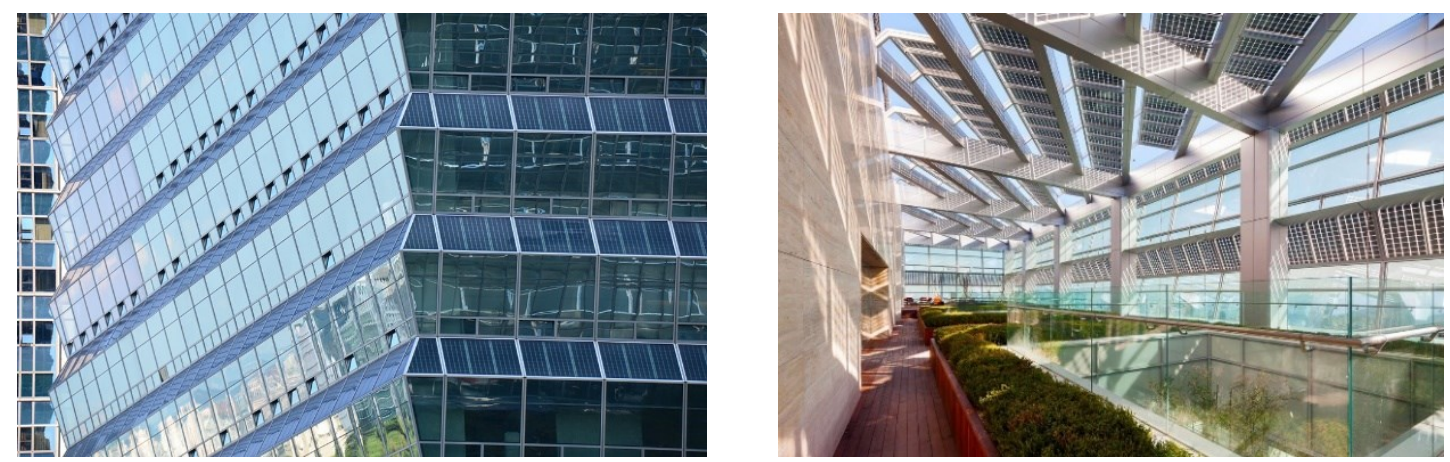

Source: Adrian Smith Gordon Gill Architecture. Federation of Korean Industries. 2013. Photograph. Federation of Korean Industries. Seoul.

Figure 2.5: (left) BIPV Façade on a skyscraper in Seoul, South Korea; (right) image of same building showing BIPV skylight and façade

The Federation of Korean Industries building in Seoul, South Korea demonstrates a straightforward design and application of various BIPV systems. Due to the functional concerns associated with the leasing and occupancy of high-rise office towers, the dimension within which its BIPV façade could have been designed was constrained both in depth as well as in expression. Since views out of the offices are valued and a rectangular floorplate is required, the architects simply tilted and substituted what would normally be infill spandrel panels with c-Si PV modules. Such a strategy only marginally increases system efficiency. On another portion of the building, c-Si cells are used as shading devices as well as on-site power generators on a skylight assembly.

The municipal office building in Aarhus, Denmark shown in figure 2.6 incorporates several types of photovoltaic modules within the expression of its façade. Similar to the Korean example, spandrel panels are substituted with tilted c-Si panels in between glazed segments. Elsewhere on the façade, a shading system incorporates solar cells in a horizontal pattern, breaking up what would otherwise be a monotonous, flat wall. 

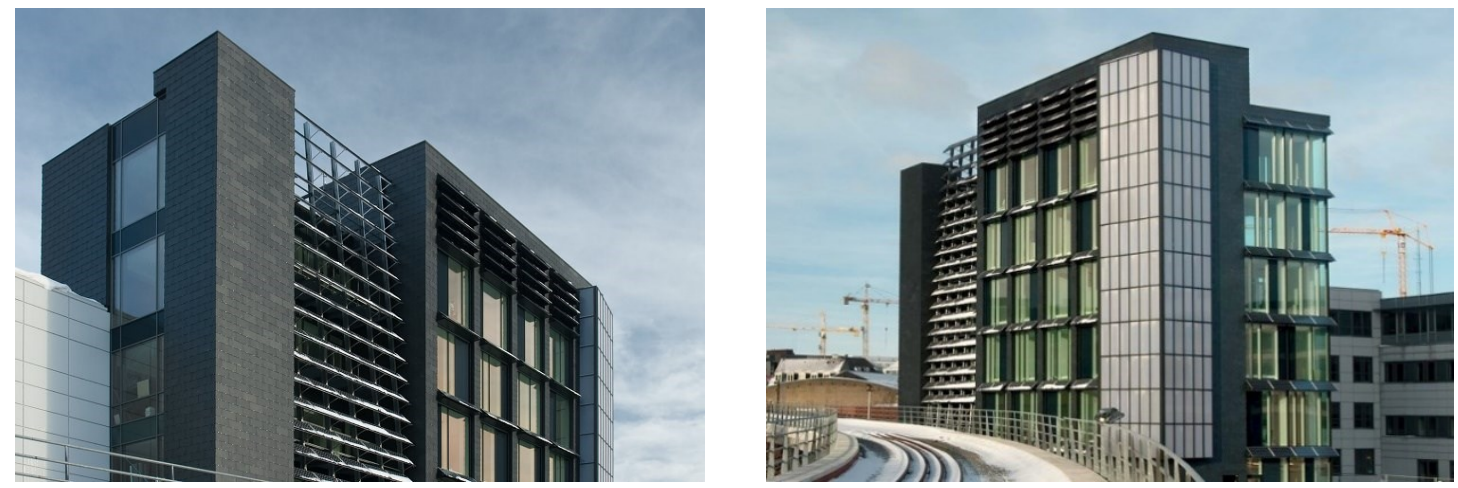

Source: C.F. Møller Architects. Low Energy Office Building. 2010. Photograph. Aarhus Municipality. Aarhus.

Figure 2.6: low energy office building in Denmark incorporating a variety of BIPV solutions
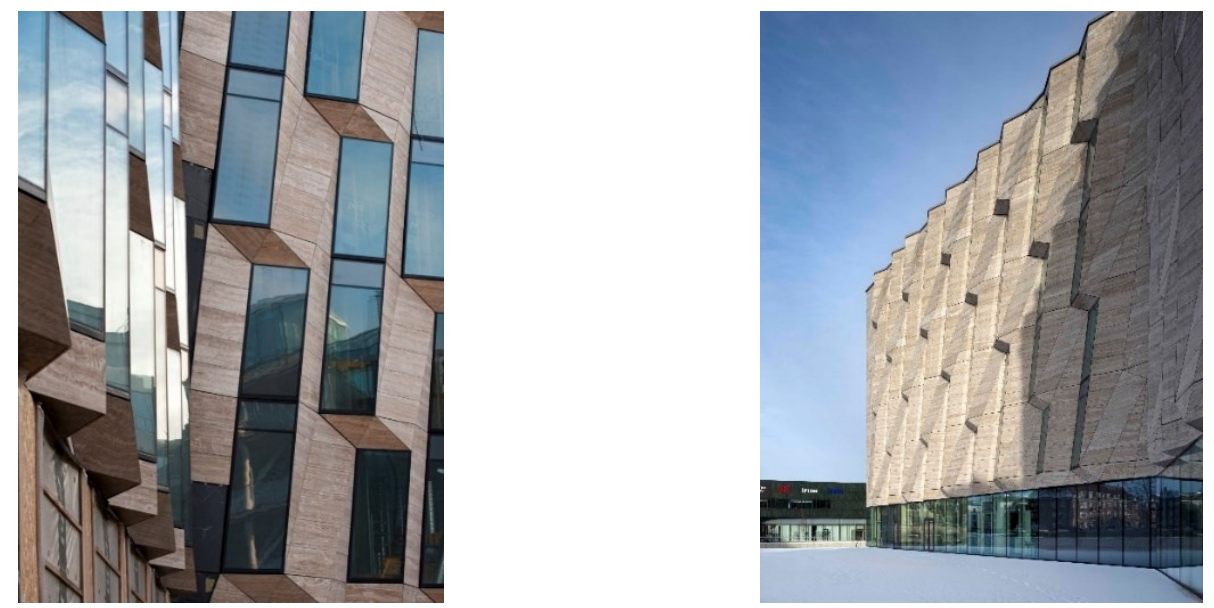

Source: Mørk, Adam. Horten Headquarters, 3XN Architects. 2009. Photograph. Carlsberg Ejendomme. Copenhagen.

Figure 2.7 façade designed to reduce internal heat gain

While not a BIPV façade, the envelope for a law firm's headquarters in Copenhagen, Denmark elegantly combines ornament and functionality. Its faceted, folded pattern is designed such that all glazed surfaces are oriented to the north, minimizing solar heat gain within the building. The glazed portions also face a canal, therefore the building is not only oriented for optimal efficiency, but is also designed to offer its users the best views of its surroundings. The façade is also novel in material composition, employing the use of fiberglass instead of steel framing. Its method of construction is technologically sophisticated and innovative in its modular assembly, yet simple in the sense that the issues it mitigates are age-old. In this case, the solution is more architectural than it is technological. The architecture itself is the primary contributor to the energy savings and 
sustainable quality of the building. Simultaneously, the three-dimensional relief of the zigzag pattern creates visual interest; from the south, the façade appears to be completely solid (figure 2.7, right); from the north, the folded pattern of glass and travertine cladding becomes distinct (figure 2.7, left). It is a far more elegant solution to shutting out excessive sunlight when compared with traditional methods that include, among others: aluminum awnings; brise-soileil; window tints; window films.
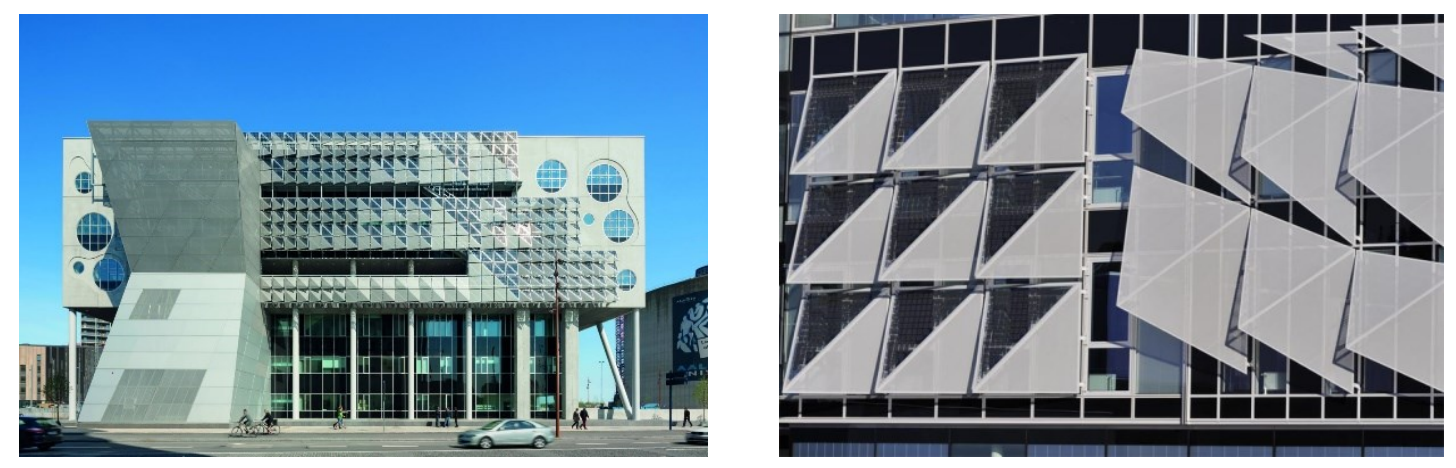

Source: Coop Himmelb(I)au. House of Music II. 2014. Photograph. North Jutland House of Music Foundation. Aalborg. Figure 2.8: (left) faceted BIPV/shading system; (right) detailed view of solar PV shading system

Musikkens Hus (figure 2.8) in Aalborg, Denmark incorporates solar PV panels within the geometry of aluminum solar shading devices on the building's southern façade. It is not clear whether the inspiration for the faceted forms came prior to or after the incorporation of the PV cells, however the result is both visually interesting and functional.

WKieran Timberlake's design for the United States chancery in London (Figure 2.9) incorporates crystalline cells behind a veil of ETFE foils draped along a second skin, outboard of the glazed building envelope. Since the ETFE foils are not inflated, the use of c-Si cells does not affect the system's structural integrity. As a result, the design mitigates wind downdrafts, generates energy, and reduces internal heat gain in one fell swoop- an elegant solution to several common problems faced by office buildings. It is noteworthy, however, that the application of a BIPV system in London's often overcast and rainy climate may not be the most cost effective method of pursuing goals in energy efficiency. 

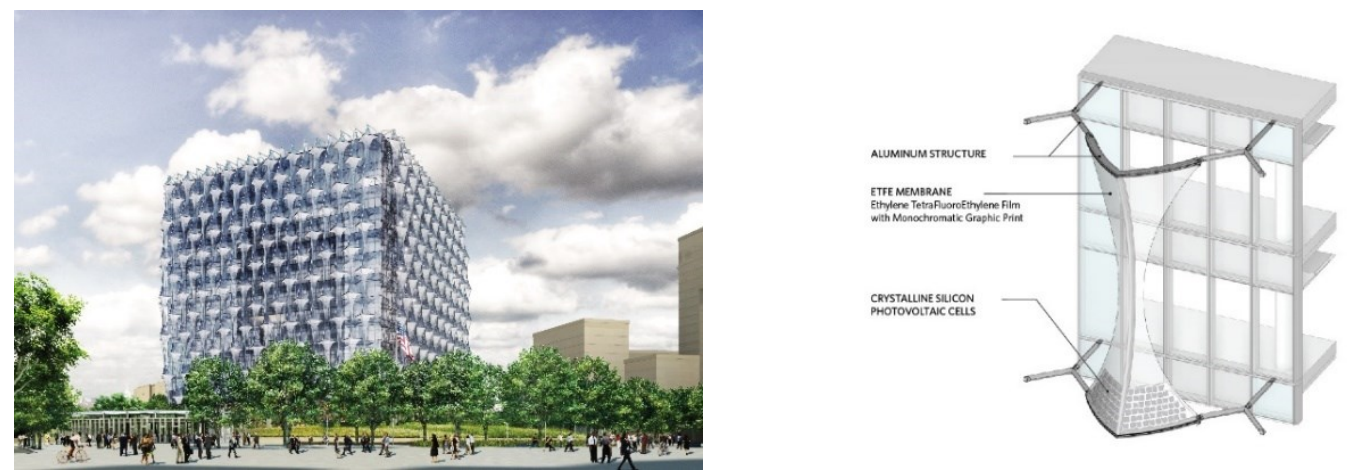

Source: Kieran Timberlake Architects. United States Chancery, London. 2017. Artist's Concept. US Department of State. Washington, DC.

Figure 2.9: (left) artist's concept of ETFE PV double skin façade; (right) detail showing connection with inner glazed surface 


\section{Methodology}

\subsection{Site Selection and Building Program}

In order to begin the investigation both the building typology and site were chosen very early in order to account for fixed variables that include climatic and urban qualities, factors contributing greatly toward determining the appropriate building form. The design project started with the search for a large site featuring largely unobstructed exposure to sun and prevailing winds. There are several greenfield and brownfield sites in Ottawa that satisfy this basic criteria, however Lebreton Flats was chosen because of a recent competition for its redevelopment and the consequential effect it will have on the city's peripheral downtown core.

In order to develop a building proposal, a need for the site's use had to be identified. The program had to be sufficiently large in mass in order to explore the thesis question, yet significant such that it offer something substantial to the city. A critical analysis of Lebreton Flats in its present and potential future conditions led to the choice of a data centre as the primary use for the proposed building. The federal government (Shared Services Canada) is consolidating its data facilities from 258 to 7 , reducing its real estate footprint from $600,000 \mathrm{ft}^{2}$ to $180,000 \mathrm{ft}^{2}$; the chosen site at Lebreton is strategically located in proximity to federal office buildings on both sides of the Ottawa River, and is therefore an ideal location for one such facility. As a result, pedestrian access, proximity to public transportation, and parking will be required. Based on this criteria the location is further justified (figure 3.1) 
not only due to it being within the federal office precinct, but also in its adjacency to the city's light rail trunk line. This is resonant with the notion that data centres are considered core elements of 'smart' cities and are necessary technological infrastructure for the foreseeable future. Consequently, the proposed building program becomes relevant at both the municipal and federal levels. As means to maximize the potential of the investigation, a secondary program consisting of various performing arts and civic amenity spaces is incorporated within the building. By integrating utility and public space, the design potential and performance of the overall renewable energy system is enhanced, allowing for synergetic relationships to exist between form and program.

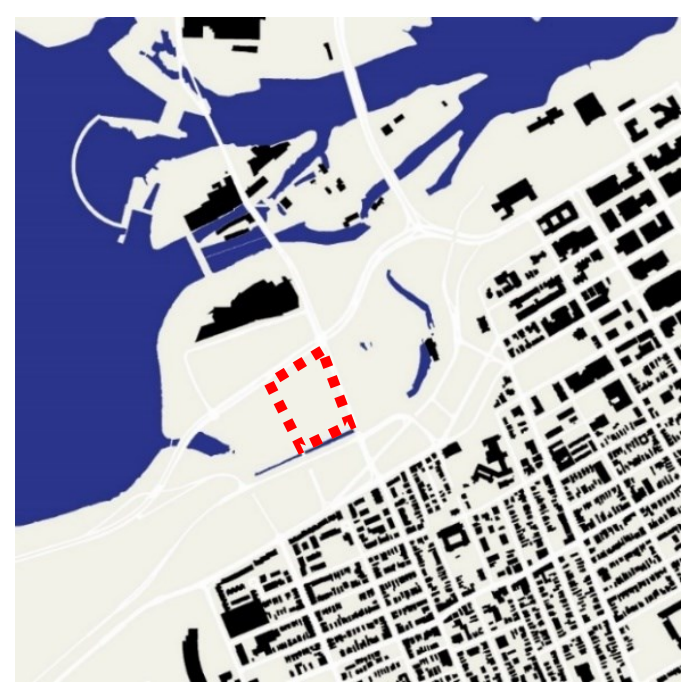

Figure 3.1: context plan showing the chosen site, outlined in red

There are immediate and ongoing plans for the Flats' redevelopment. A catastrophic fire in 1900, bureaucratic fumbling, and issues related to contamination halted development on Lebreton Flats for decades. The winning proposals for its masterplan by Claridge (2004) and RendezVous LeBreton Group (2016) have proposed what is essentially a residential neighbourhood, though a variety of smaller public buildings and outdoor spaces are scattered throughout- including a large stadium (figure 3.2). In contrast, both the Gréber Report (circa 1950) and National Capital Commission (NCC) 2005 federal land use plan called for a variety of programming that are still not only municipally relevant, but nationally significant since the property is immediately adjacent to the capital's ceremonial 
route. The former industrial and residential properties on Lebreton Flats were expropriated by the NCC in the early 1960s and subsequently demolished in order to fulfill what the Gréber report mandated- buildings and monuments of 'national significance.' The winning schemes are at odds with the mid-century masterplan and development thus far. Based on the city's soft residential market and current condominium development on nearby Chaudière Island, the proposed program is arguably stronger and more relevant to Lebreton's storied identity than the 2004 and 2016 schemes.

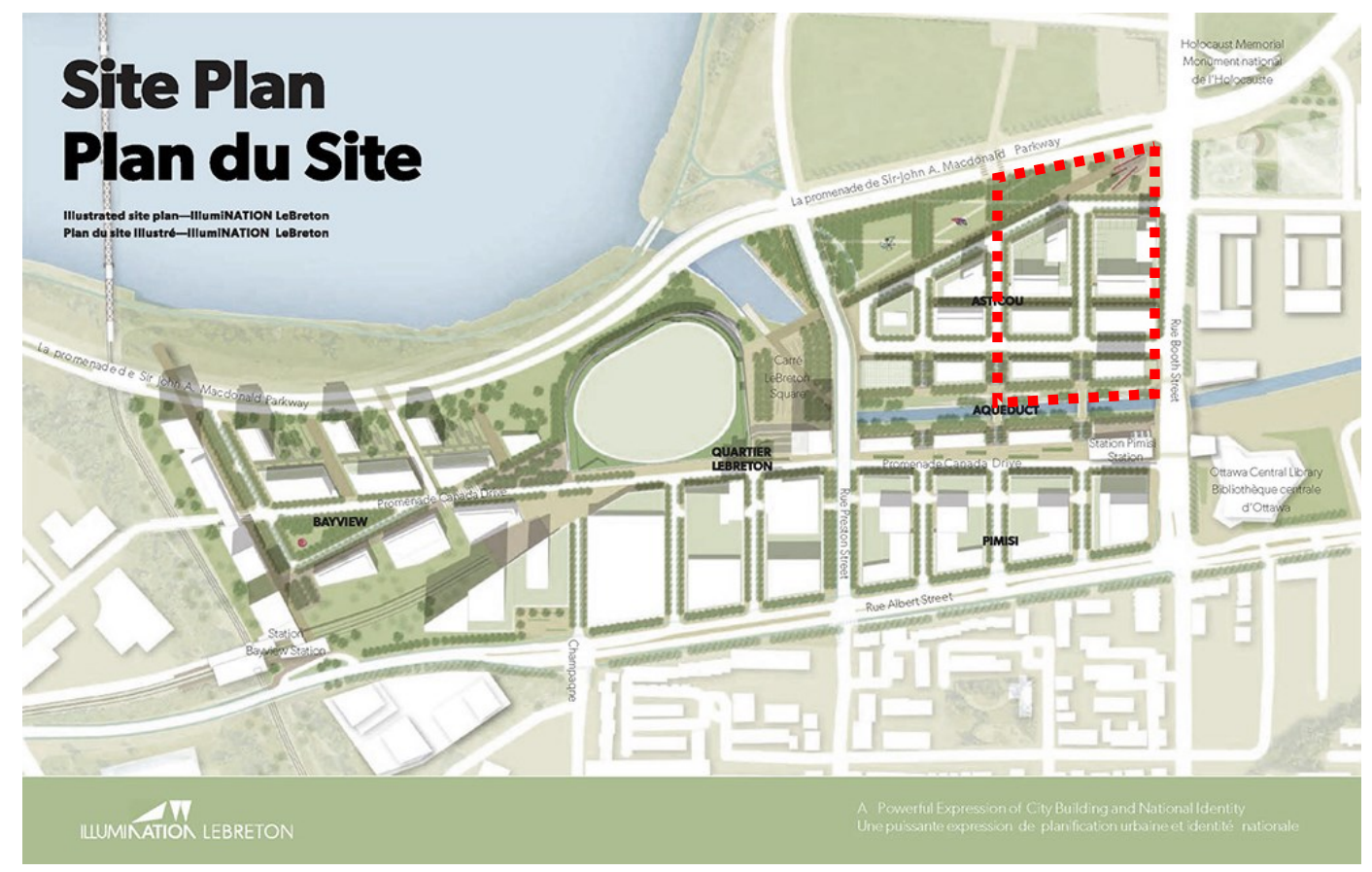

Source: The National Capital Commission

Figure 3.2: RendezVous LeBreton Group's winning proposal (2016) for the masterplanning of Lebreton Flats' remaining undeveloped portions; (outlined in red) the chosen location for the proposal

From a morphological perspective, the size of and typology of the proposed building is in keeping with the spirit of its immediate surroundings. The Canadian Museum of War (Moriyama Teshima, 2005) is immediately across the road from the site, and the Holocaust Monument (Studio Libeskind, 2017, seen in figure 3.2) is currently under construction on the opposite corner. Both structures are equally striking and feature agonized, angular forms juxtaposed against the flat landscape. They are also culturally significant 
monuments, therefore the proposal for another physically and programmatically unique building is arguable and fitting within such a context. Though not adjacent to Lebreton, the Library and Archives Canada building is prominently located on an escarpment that overlooks the Flats, and the site for the new main branch of Ottawa Central Library also overlooks Lebreton; a data centre for the federal government is an appropriate counterpoint to these institutions.

The choice of an appropriate location for a data centre is influenced by several factors, particularly the method and purpose of its operation. They are typically located in proximity to power grids, telecommunications infrastructure, transportation lines, as well as their users. These are all factors which affect risk, security, and privacy-critical to such facilities since governments and corporations depend on their ceaseless and reliable operation in order to conduct business. Data centres do not only act as repositories for digital information, they are also mission critical components of various enterprises. Further to security concerns, climate is also a factor in the selection of a building site; cold climates are favoured since they offer a source of free cooling. Owing to these requirements, there are several precedents for data centres in urban locations (table 3.1), however none feature building integrated renewable energy systems, including photovoltaics.

The closest and most comparable facility is located in downtown Toronto (figure 3.4). The TR2 Equinix data centre is one of two colocation spaces (the other being TR1) that serve many of the city's financial services and financial exchange customers, as well as other enterprises in the downtown core. It is a mere two kilometers away from the majority of its clients. By virtue of the financial industry's time sensitive, secure nature, the facility is a 24 hour, 365 day a year, secure operation. The older Equinix facility, TR1, is within walking distance of Toronto's major financial institutions. Both facilities are connected through fibre optics in order to provide a fast and secure connection. 

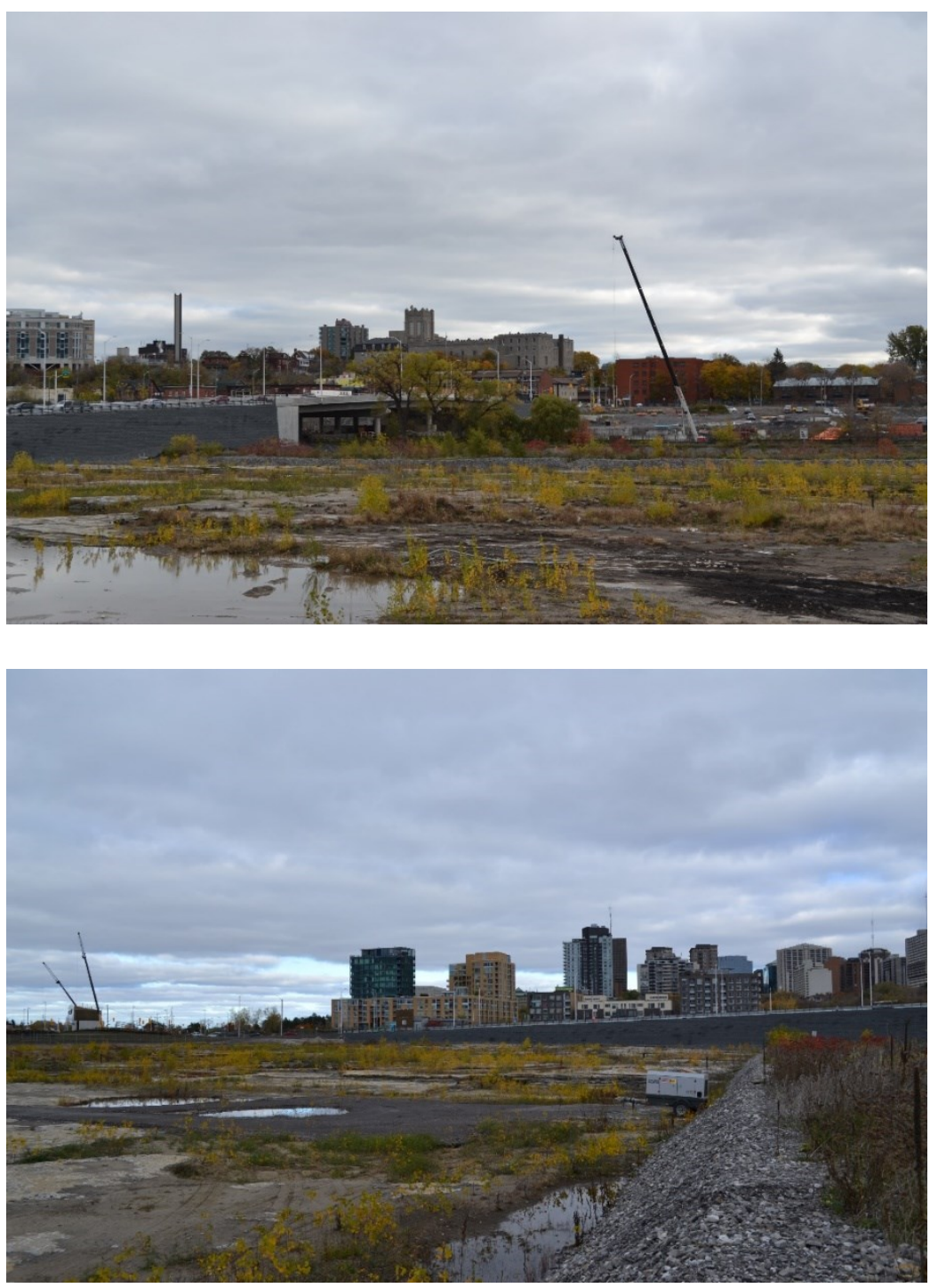

Figure 3.3: (top) site photo looking south-east; (bottom) site photo looking south-west
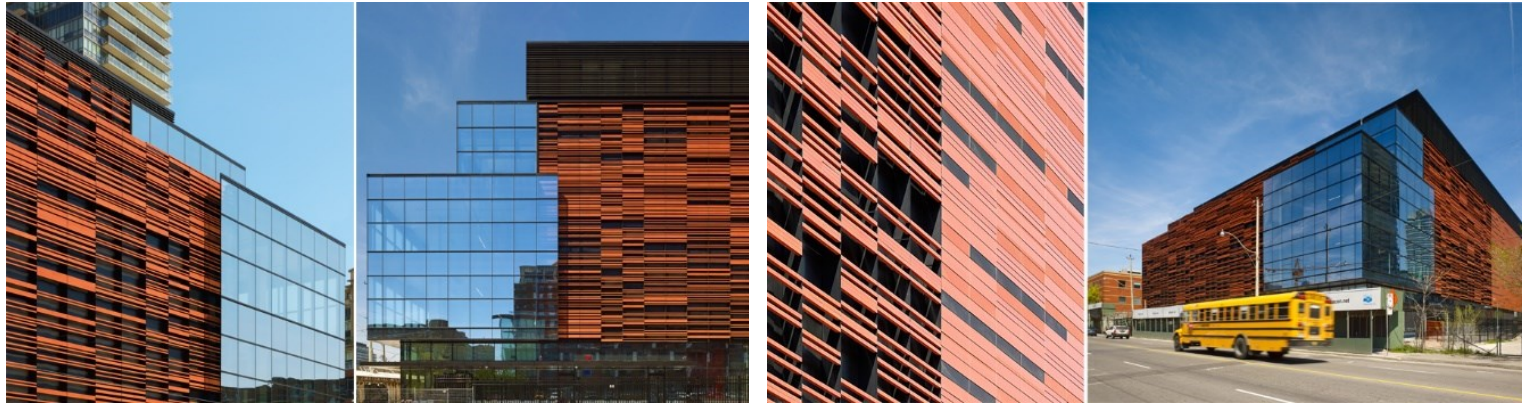

Source: WZMH Architects. 45 Parliament Street Data Centre. 2013. Photograph. Urbacon Data Centre Solutions Incorporated. Toronto

Figure 3.4: 22,000 ${ }^{2}$ Equinix data centre in Toronto's distillery district 
Programmatically, data facilities are relatively straightforward in their layout (figure 3.5), however they have a degree of flexibility in built form that is conducive to the integration of building integrated photovoltaics: single or multi-storey format; varying slab-to-slab heights and wall types; structural grid, building envelope and foundation design; raised floor design; secure vehicular access.

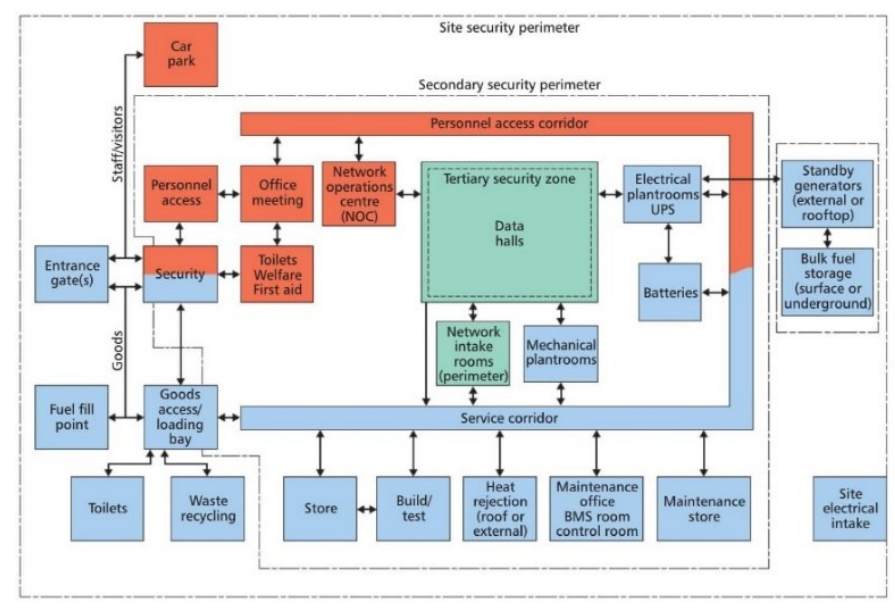

Source: Harrison, Jim. Data Centres: An Introduction to Concepts and Design. N. p.: n.p., 2012. Print.

Figure 3.5: functional program of a typical data centre, showing relationship between spaces and paths of circulation 


\subsection{Defining Size}

Data centres have a high power density and heat load, normally expressed in $\mathrm{kW}$ and $\mathrm{W} / \mathrm{m}^{2}$ per rack, respectively (table 3.1). Comparable facilities to the size proposed by Shared Services Canada were summarized and average figures were derived based on the findings (table 3.2) in order to facilitate the estimation of size and energy consumption values for the building.

\begin{tabular}{|c|c|c|c|c|}
\hline Density & $\begin{array}{l}\text { Heat Load per } \\
\text { rack }(\mathrm{kW})\end{array}$ & $\begin{array}{l}\text { Power Density } \\
\left(\mathrm{W} / \mathrm{m}^{2}\right)\end{array}$ & $\begin{array}{l}\text { Typical Cooling } \\
\text { Medium }\end{array}$ & Cooling Systems \\
\hline Low Density & $1-7$ & $500-900$ & Air & $\begin{array}{l}\text { CRAC or CRAH units } \\
\text { All-air Systems }\end{array}$ \\
\hline Medium Density & $\begin{array}{c}8-10 \\
10-14\end{array}$ & $900-1500$ & $\begin{array}{l}\text { Air } \\
\mathrm{CW} / \text { refrigerant/ca } \\
\text { rbon dioxide }\end{array}$ & $\begin{array}{l}\text { Hot or cold aisle } \\
\text { containment } \\
\text { Containment and in-row } \\
\text { liquid cooling }\end{array}$ \\
\hline High Density & $15-24$ & $5000+$ & $\begin{array}{l}\mathrm{CW} / \text { refrigerant/ca } \\
\text { rbon dioxide }\end{array}$ & $\begin{array}{l}\text { Cabinet/rear door liquid } \\
\text { cooling }\end{array}$ \\
\hline High Density plus+ & $25+$ & $8000+$ & $\begin{array}{l}\mathrm{CW} / \text { refrigerant/ca } \\
\text { rbon dioxide }\end{array}$ & $\begin{array}{l}\text { Cabinet/rear door liquid } \\
\text { cooling }\end{array}$ \\
\hline
\end{tabular}

Source: Harrison, Jim. Data Centres: An Introduction to Concepts and Design. N.p.: n.p., 2012. Print.

Table 3.1: guidance on power density and heat load of cabinets, based on average performance across a number of installations

Maximizing efficiency within a building's energy load is the first step toward developing a design for a BIPV application. For a data centre, this involves specifying low energy HVAC systems, as well as incorporating passive cooling systems and strategies into its design; the racks have a significant heat load (table 3.1) which require enormous amounts of cooling, resulting in a large quantity of electricity used for climate control systems. Data centre operators that advertise 'green' or 'low energy' facilities typically use evaporative or liquid cooling systems, both of which are major consumers of potable water resources. The use of water- a scarce resource which itself requires electricity for treatment- for energy use reduction is simply not the right approach. Furthermore, evaporative cooling systems have been identified as major contributors to sick building syndrome, therefore requiring supervision and regular maintenance- adding cost. This is where using renewable energy 
systems within buildings to produce energy can in fact be more 'sustainable' than simply reducing a building's HVAC load. The solution lies in striking a careful balance between energy production and consumption.

\begin{tabular}{|l|l|l|l|}
\hline Provider and Location & Facility Size ${ }^{1}$ (sq.ft.) & Facility Power (MW) & Operation \\
\hline $\begin{array}{l}\text { MTS Data [12] } \\
\text { (Manitoba) }\end{array}$ & 64,000 & 7.5 & $24 / 7 / 365$ \\
\hline $\begin{array}{l}\text { Equinix [11] } \\
\text { (Toronto) }\end{array}$ & 168,000 & 16 & $24 / 7 / 365$ \\
\hline $\begin{array}{l}\text { TeraGo [14] } \\
\text { (Kelowna) } \\
\text { Cogeco [15] } \\
\text { (Barrie) }\end{array}$ & 17,000 & 6 & $24 / 7 / 365$ \\
\hline
\end{tabular}

${ }^{1}$ IT whitespace only

Table 3.2: size and capacity of various Canadian data centres

Specifying low power server racks and light fixtures is also important, as they are the two most onerous loads after the building's climate control system, though to a far lesser extent. Passive cooling is particularly important since Ottawa is in a cold climate zone. This first step offers the investigation a degree of flexibility when designing the BIPV envelope, since the amount of photovoltaic modules can be reduced or increased, depending on the desired aesthetic and functional outcome. Since the incorporation of passive cooling strategies is dependent on building form and program layout, the design exercise has to be conducted in tandem with the second step, discussed in section 3.3.

\subsection{Building Form}

\subsubsection{Optimization for Energy Capture}

For any given location of a photovoltaic installation, determining the optimal tilt angle and azimuth for an array is the second most important step in designing an effective system, as well as the first true architectural exercise in the design process. Maximizing annual energy production is highly dependent on orientation (Kemery et al. 236). Whereas most built examples of building-integrated PV systems simply substitute building components 
with PV modules, this investigation conceptualizes a design that considers issues of site and program in order to inform and maximize the design and performance of the BIPV envelope. Manipulating building form and/or building components are the simplest methods of adjusting orientation, since the proposed building is entirely new construction with few site constraints. This exercise involves an optimization of form for passive cooling as well as an optimization for solar energy production. Table 3.3 lists the optimal orientation of PV panels for 10 Canadian cities, including Ottawa. Basic massing models were subsequently made using computer software, based on the latitude and tilt data provided.

\begin{tabular}{|l|l|l|l|l|}
\hline City & Latitude (Degrees) & Tilt Angle (Degrees) & $\begin{array}{l}\text { Azimuth Angle } \\
\text { (Degrees) }\end{array}$ & $\begin{array}{l}\text { Latitude - Tilt } \\
\text { (Degrees) }\end{array}$ \\
\hline Shearwater & 44.6 & 38 & 2 & 6.6 \\
\hline Winnipeg & 49.9 & 43 & -2 & 6.9 \\
\hline Calgary & 51.1 & 44 & 0 & 7.1 \\
\hline Ottawa & 45.5 & 38 & -3 & 7.5 \\
\hline Quebec City & 46.8 & 39 & 0 & 7.8 \\
\hline Charlottetown & 46.3 & 38 & 2 & 8.3 \\
\hline Victoria & 48.7 & 36 & 7 & 10.7 \\
\hline St. John's & 47.5 & 36 & 5 & 11.5 \\
\hline Vancouver & 49.2 & 36 & 12 & 13.2 \\
\hline Whitehorse & 60.7 & 44 & -4 & 16.7 \\
\hline Average & & & 1.9 & 9.6 \\
\hline
\end{tabular}

Source: Kemery, Briana Page, lan Beausoileil-Morrison, and lan H. Rowlands. eSim 2012: The Canadian Conference on Building Simulation. May 1-4, 2012, Dalhousie University, Halifax, Nova Scotia, Canada.

Table 3.3: Orientation for maximum annual energy production in 10 Canadian Cities (SW denoted as [+], SE azimuth denoted as [-])

The insolation on the models' surfaces was simulated using a plug-in for Revit. The 'control' model (figure 3.6, left) represents the standard form of data centre (rectangular prism), while the 'experimental' model (figure 3.6, right) is rotated to the optimal azimuth, and has a tilted surface which corresponds with the optimal angle listed for Ottawa. The results of the simulation graphically verify the data in table 3.3; the brighter the colour, the greater the amount of insolation. As shown in figure 3.6, orientation has the most significant influence on the form of the overall building, and consequently any proposed design solutions. 

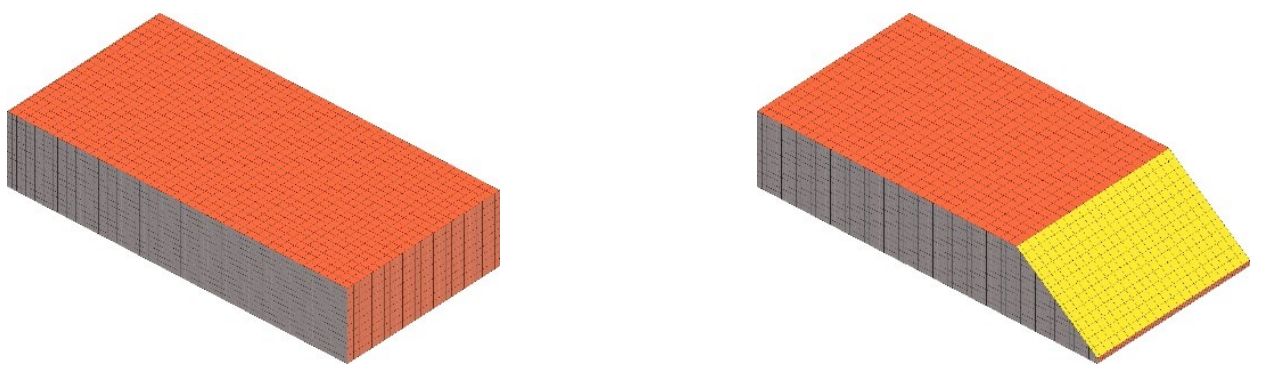

Figure 3.6: (left) volume representing a rectangular prism; (right) volume with south façade tilted at 38 degrees; yellow represents highest levels of irradiance, grey represents lowest levels

Throughout the early exercises of form exploration it became clear that practical changes to geometry (i.e. forms initially designed to capture a greater amount of solar energy) had significant potential to become programmatic and decorative elements within the overall scheme for the building. For example, increasing the surface area of the exterior building envelope (figure 3.7, left) while also tilting the façade (figure 3.7, right) produces an interesting design that also generates more energy. These investigations informed subsequent massing studies that eventually became the design for the project of architecture, seen in figure 3.8 .
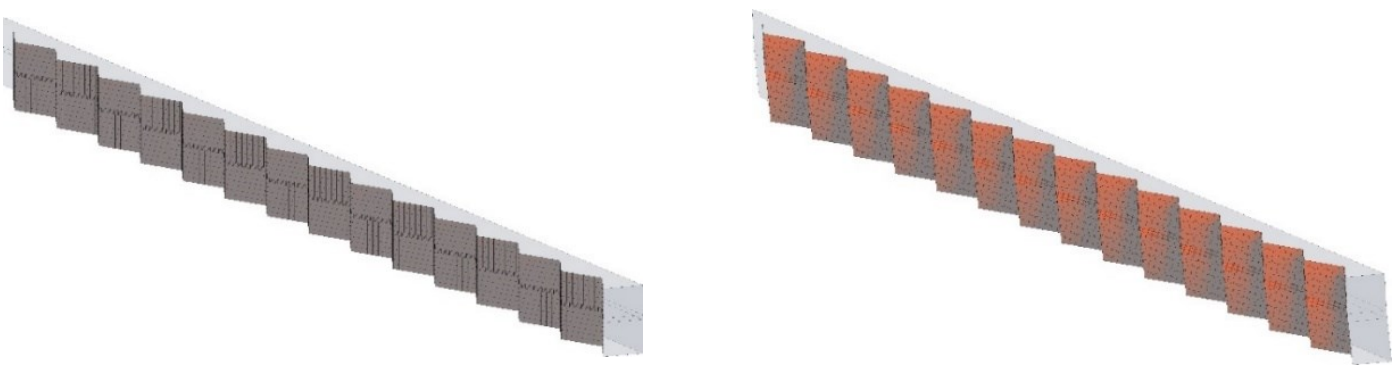

Figure 3.7: (left) sawtooth exterior skin pattern tilted at $90^{\circ}$; (right) sawtooth exterior skin tilted at $38^{\circ}$; orange represents highest levels of irradiance, grey represents lowest levels

The design for the building's mass first addressed the issue of accommodating its physical program as well as the challenge of capturing solar energy. This required the allocation of space for a double skin envelope with a minimum height of 16 meters, and a depth varying between 1-2 meters, based on both the programmatic and technical requirements of the building typology and technology, respectively. 
Envisioned is a three-part building; the southern volume (figure 3.9, far left) contains the data facility as well as a performing arts hall on its uppermost level- it is the building's largest physical component and greatest energy producer; the northern volume (figure 3.9, far right) replaces a bandshell platform for Ottawa's annual Bluesfest with indoor and outdoor theatres; the northern and southern volumes are connected by a bridge (figure 3.9, center) that spans a five lane parkway, connecting the inland and waterfront portions of Lebreton Flats. Overall, the building reads as a singular form that sweeps across the landscape, oriented to capture the greatest amount of solar energy while sheltering its occupants from Ottawa's prevailing winds- particularly strong due to the site's adjacency and exposure to the river.

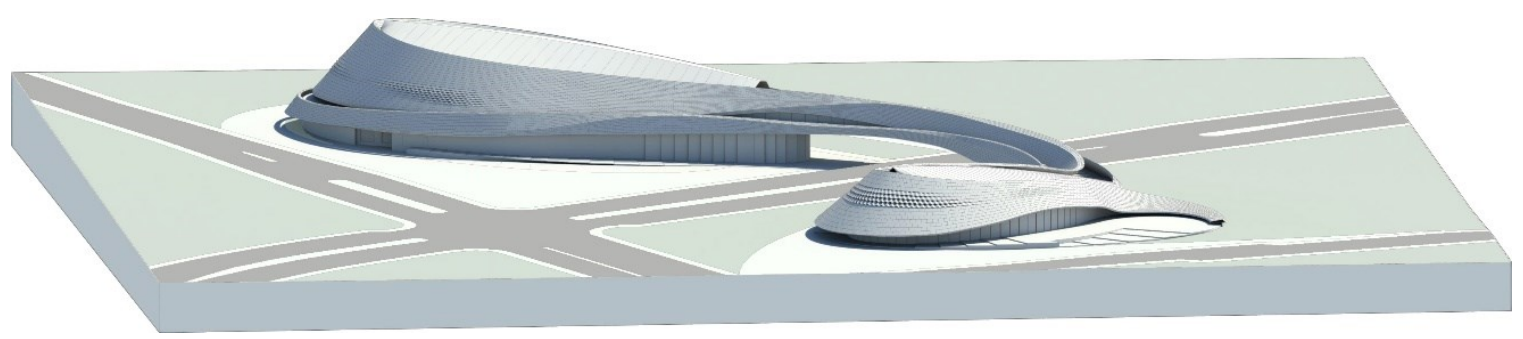

Figure 3.8: aerial perspective of the massing for the project of architecture

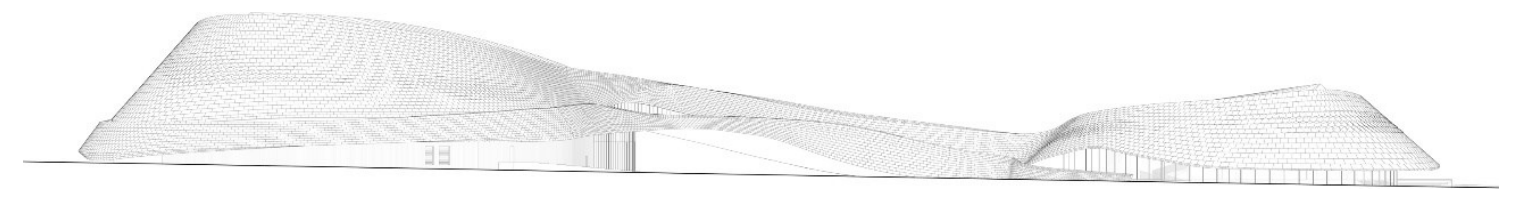

Figure 3.9: southeast elevation of the proposed building

The building's curved and tilted surface sweeps along all sides, varying in depth and height, depending on orientation. From a performance perspective, a curved outer envelope increases the surface area exposed to the sun and mitigates the potential for snow accumulation that could potentially obscure the photovoltaic panels; when compared to a rectangular prism, the curved form is more efficient. 


\subsubsection{Building Plan and Section}

Experientially and aesthetically, the envelope contributes to the character of the interior and exterior spaces of the structure and is deep enough to be inhabitable; on the northeastern side of the building, the space in between the inner and outer layers contains a semi-covered pedestrian footbridge that traverses the five lane parkway. It is a distinguished feature on all levels, seamlessly connecting both sides of the building, seen in plan (figures 3.13 and 3.14). 


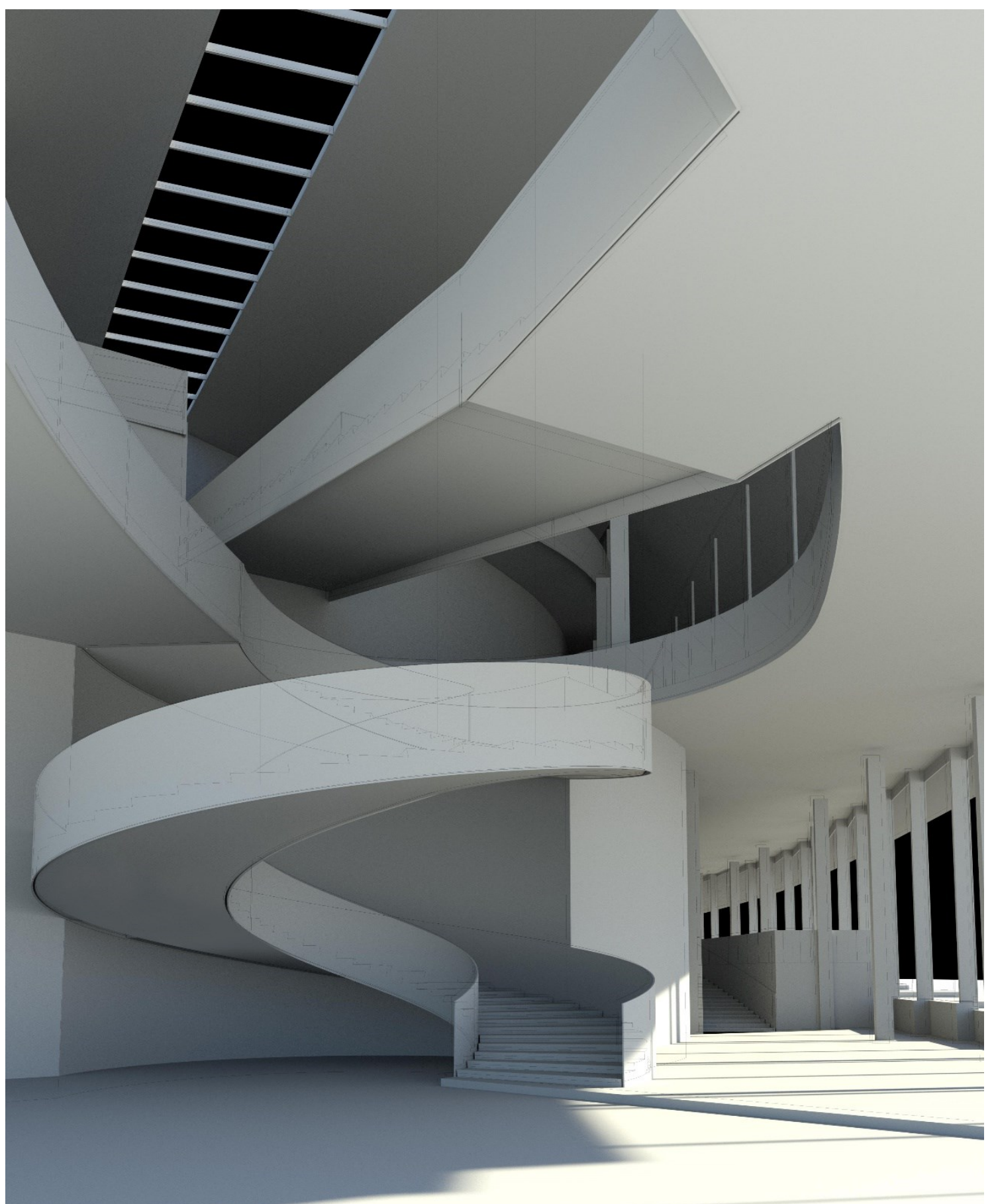

Figure 3.10: perspective showing the interior lobby space 


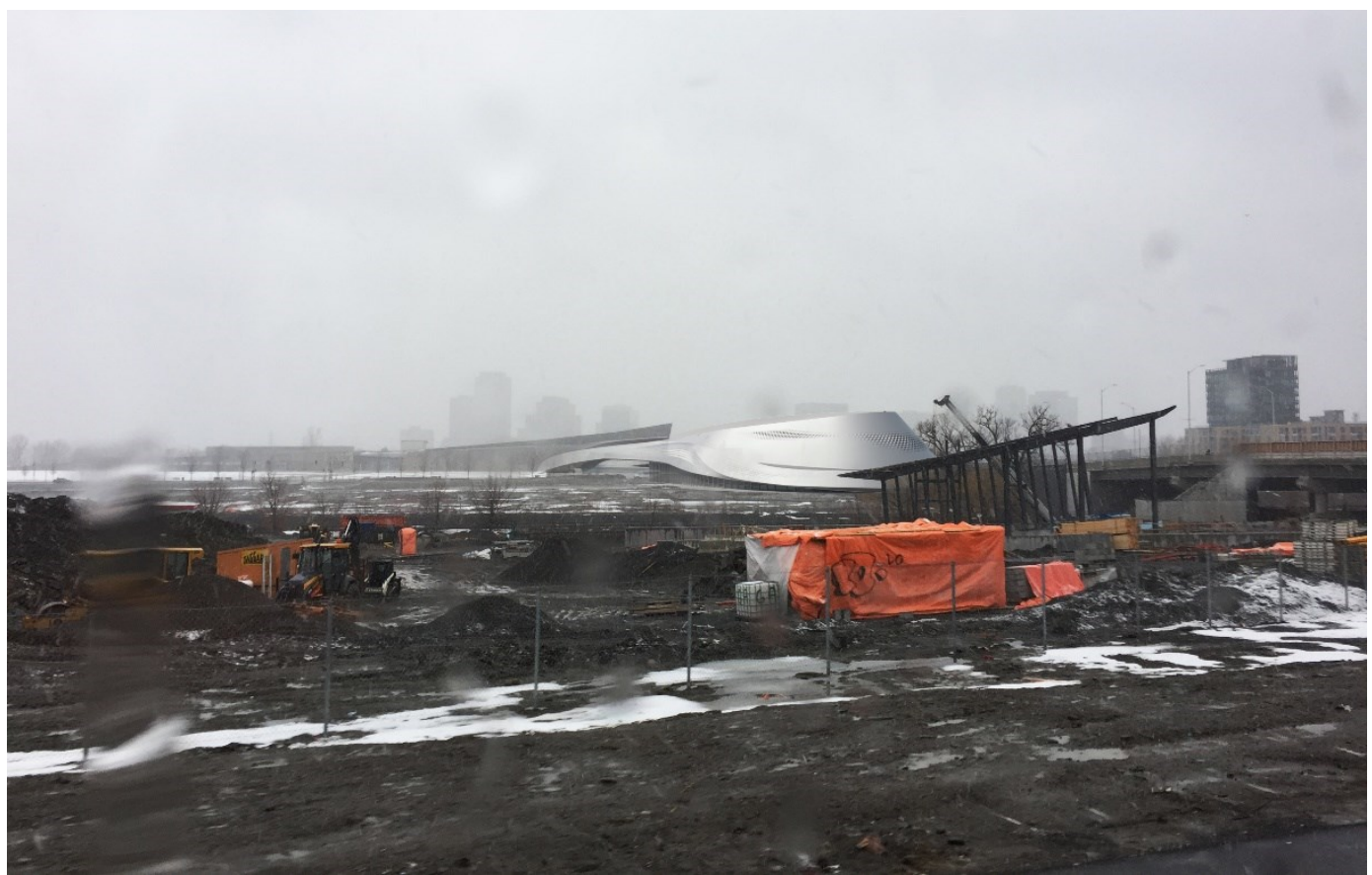

Figure 3.11: perspective from Albert Street showing the proposed building in context; (foreground) new light rail station under construction; (background) the Canadian War Museum

The sweeping roof is prominent within all publicly accessible spaces, informing visitors of its unique function, visible in section (figure 3.12). The resulting design demonstrates a direct relationship between form, program and function.
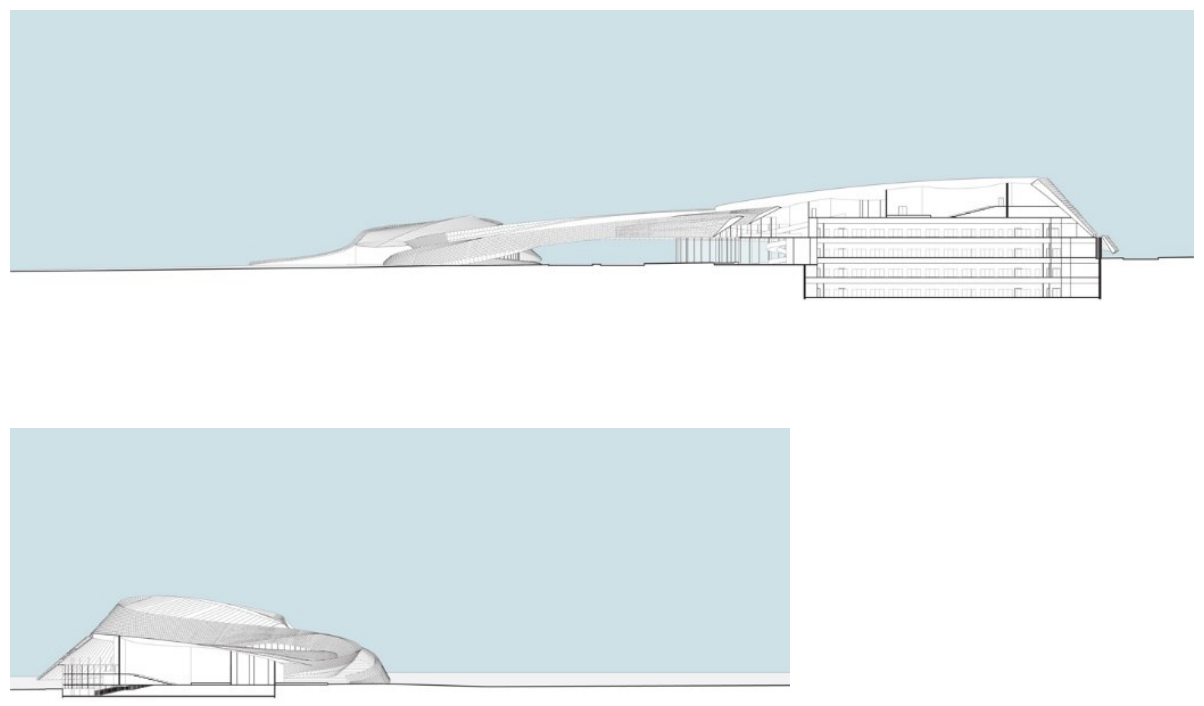

Figure 3.12: (top) north-south section through data centre and third level performing arts hall, showing bridge (center) and bandshell (far left); (bottom) east-west section through the bandshell and ground level performing arts hall 

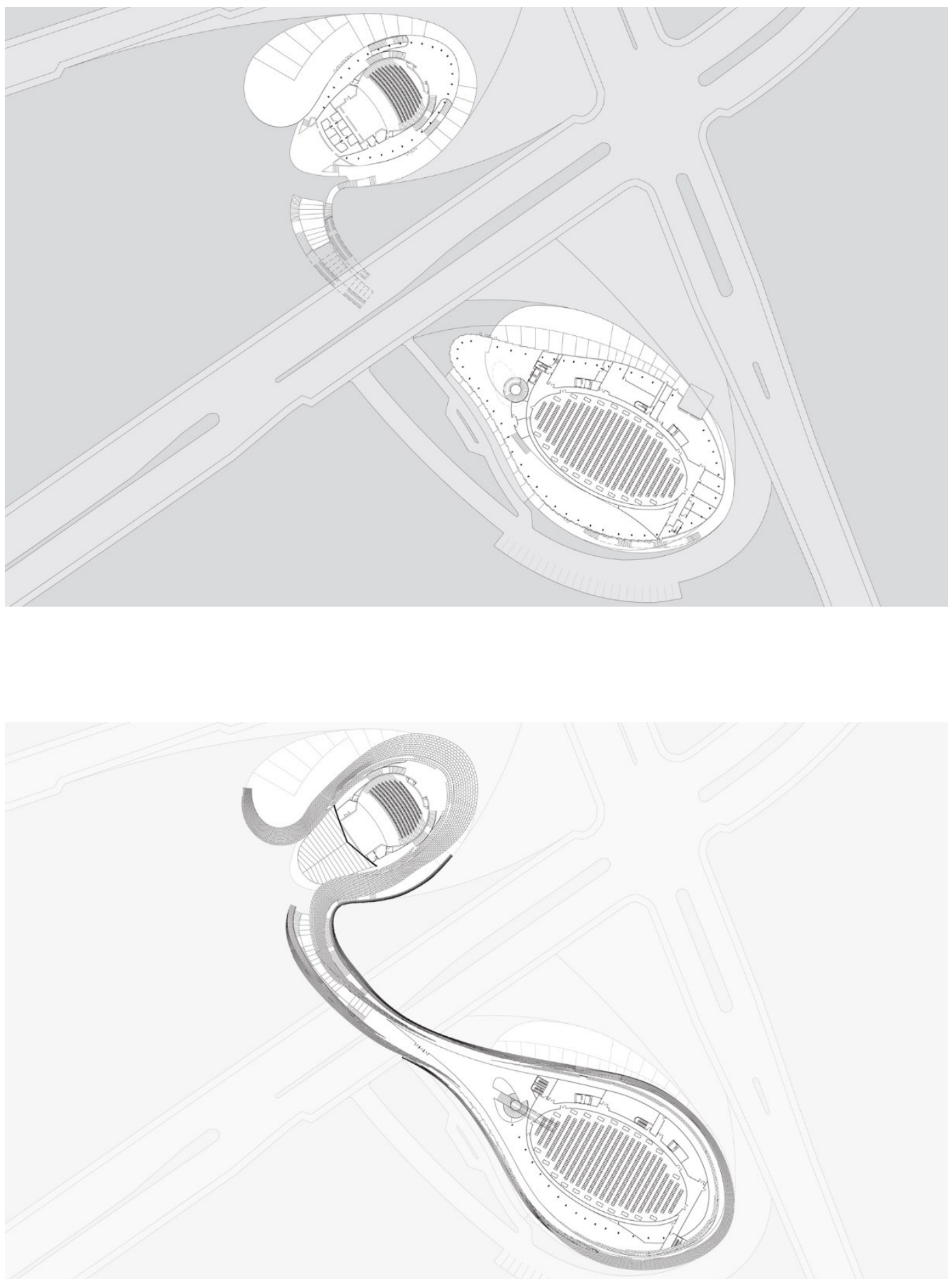

Figure 3.13: (top) ground floor plan showing bandshell, public lobby, performing arts, and data halls; (bottom) second floor plan showing public lobby, bridge, performing arts, and data halls 

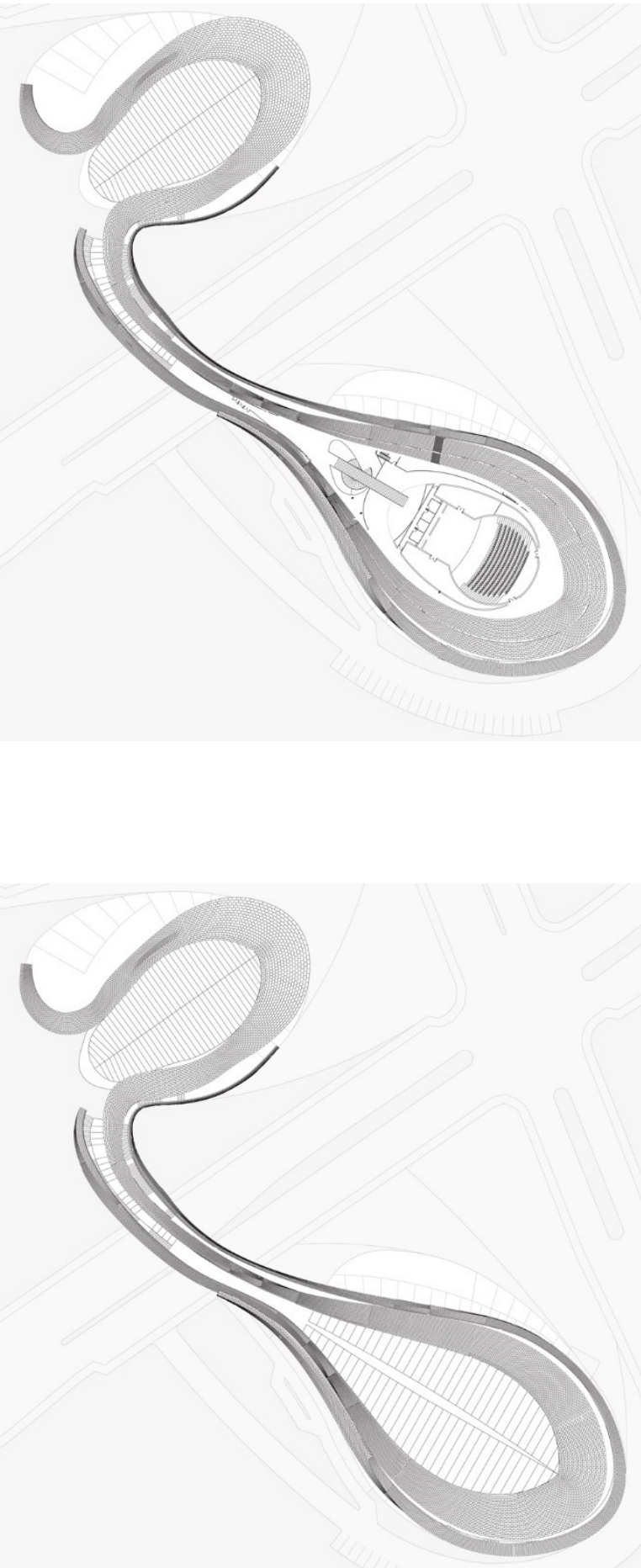

Figure 3.14: (top) third floor plan showing performing arts hall; (bottom) roof plan 


\subsubsection{Incorporation of Passive Strategies}

Ottawa is in ASHRAE climate zone 6; wind conditions and snow cover both have the potential to increase energy production and reduce energy consumption, depending on the design of the building and its envelope. Due to its high albedo, snow cover in proximity to photovoltaic modules on the exterior surface can increase their energy production by up to $10 \%$ (Norton et al. 1639), compensating for reduced daylight hours during winter months. Because of this, the outer skin is designed to be proximal to potential snow cover on the landscape surrounding the building (figure 3.17), thereby capturing ground reflected diffuse irradiance. Furthermore, the hardscape immediately adjacent to the building is designed with light coloured material, imitating the effect of snow during nonwinter seasons.

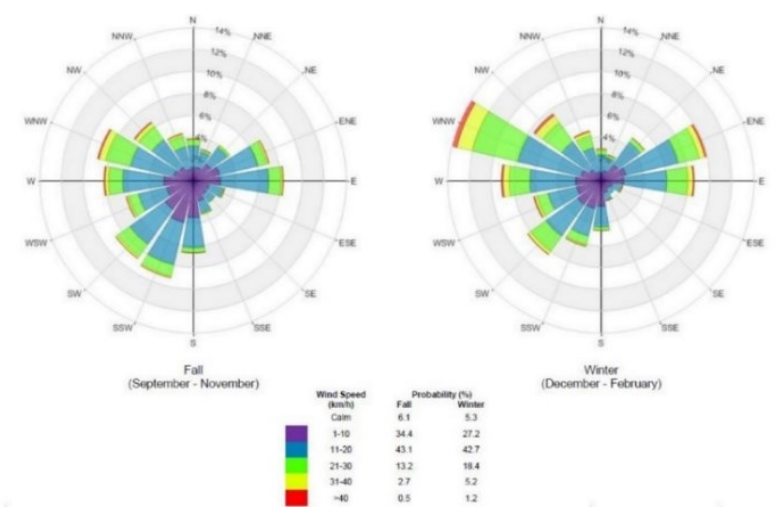

Source: the City of Ottawa Terms of Reference

Figure 3.15: prevailing winds in the Ottawa region during 2013

Wind also contributes toward higher levels of energy production due to its significant cooling effects. Consequently, the panels for the exterior envelope are envisioned as both passive and active elements. High temperatures reduce the efficiency of PV modules; since wind has a far greater cooling effect than forced air systems, a multiple-inlet BIPV/T system is proposed for the exterior envelope. Individual panels are twisted to varying degrees in order to optimize airflow behind them, and through the double skin façade. Multiple inlets are integrated along certain portions of the northwestern and southwestern facades (figures 3.16-19) since they have the greatest exposure to the sun's peak hours of 
insolation, as well as the city's fastest prevailing wind directions (figure 3.15). Such systems have been proven to counter the effect of temperature stratification (Yang et al. 2066), lowering PV temperatures along the path of the air channel, increasing the efficiency of the system by up to $7 \%$. Segments of the façade that are not susceptible to higher temperatures are designed to incorporate a single cavity system, since the extra ventilation is not needed to mitigate issues related to heat.

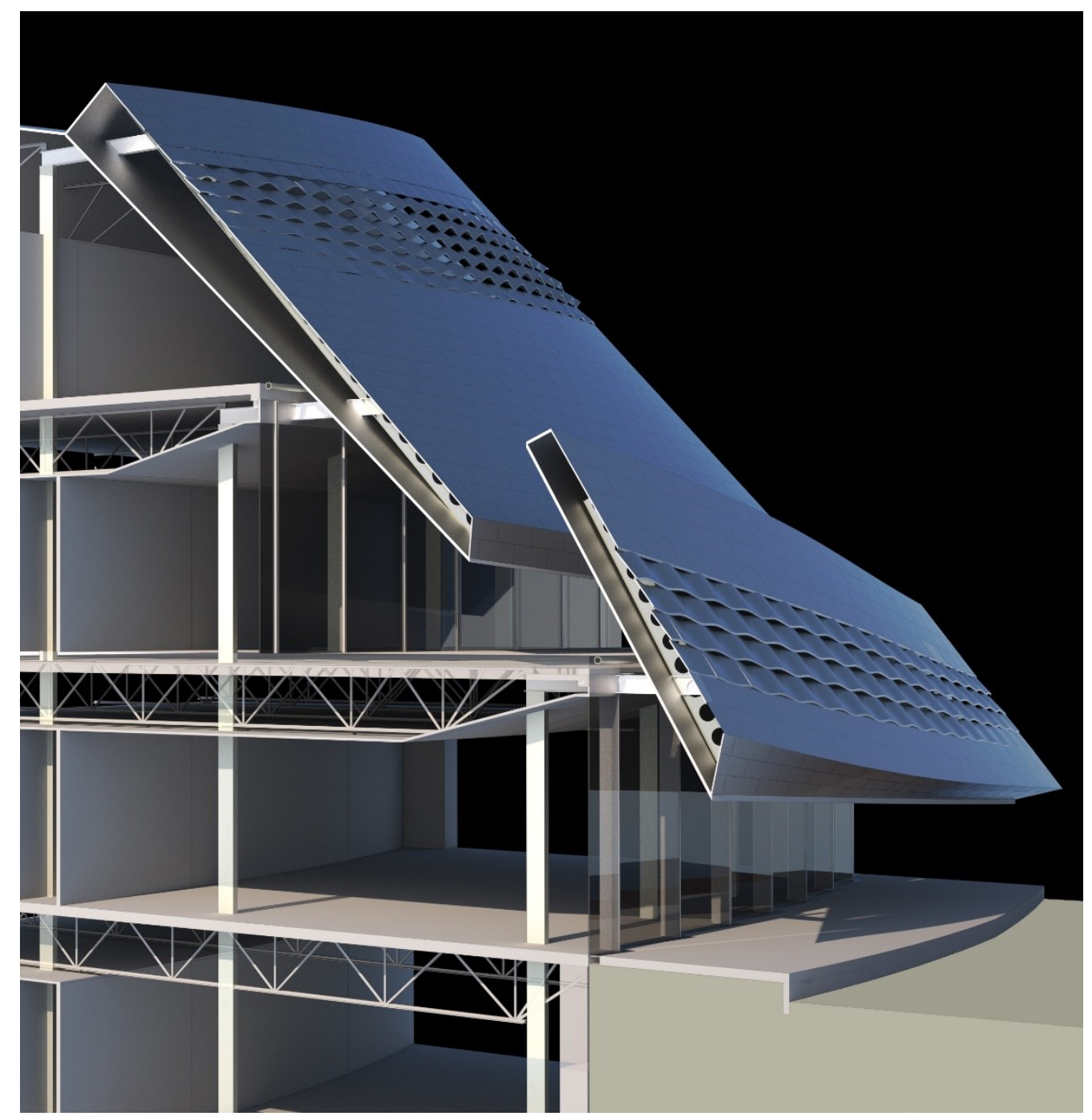

Figure 3.16: section perspective showing the exterior surface, featuring a multiple-inlet system 


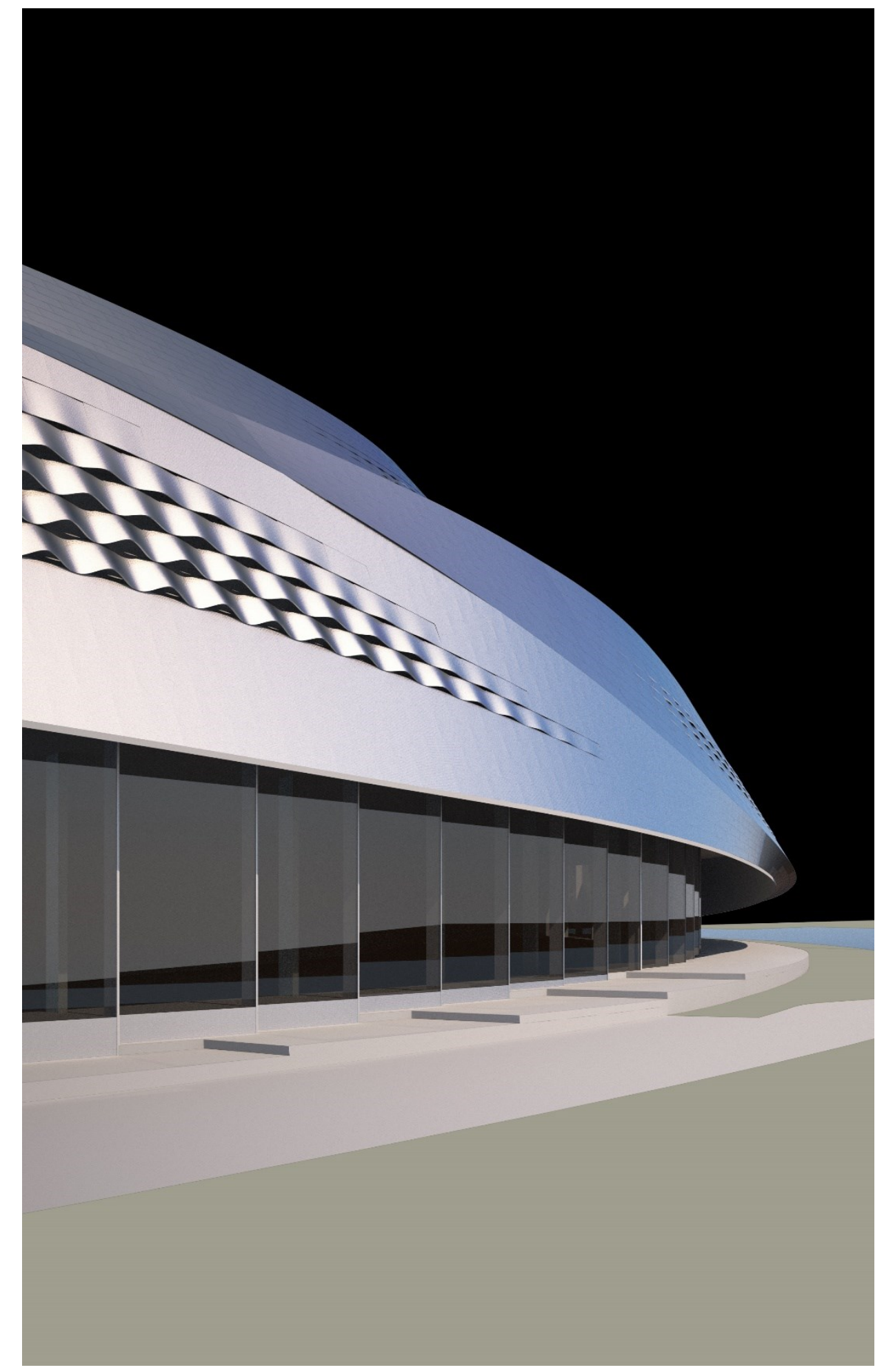

Figure 3.17: perspective showing the exterior surface, featuring a multiple-inlet system 


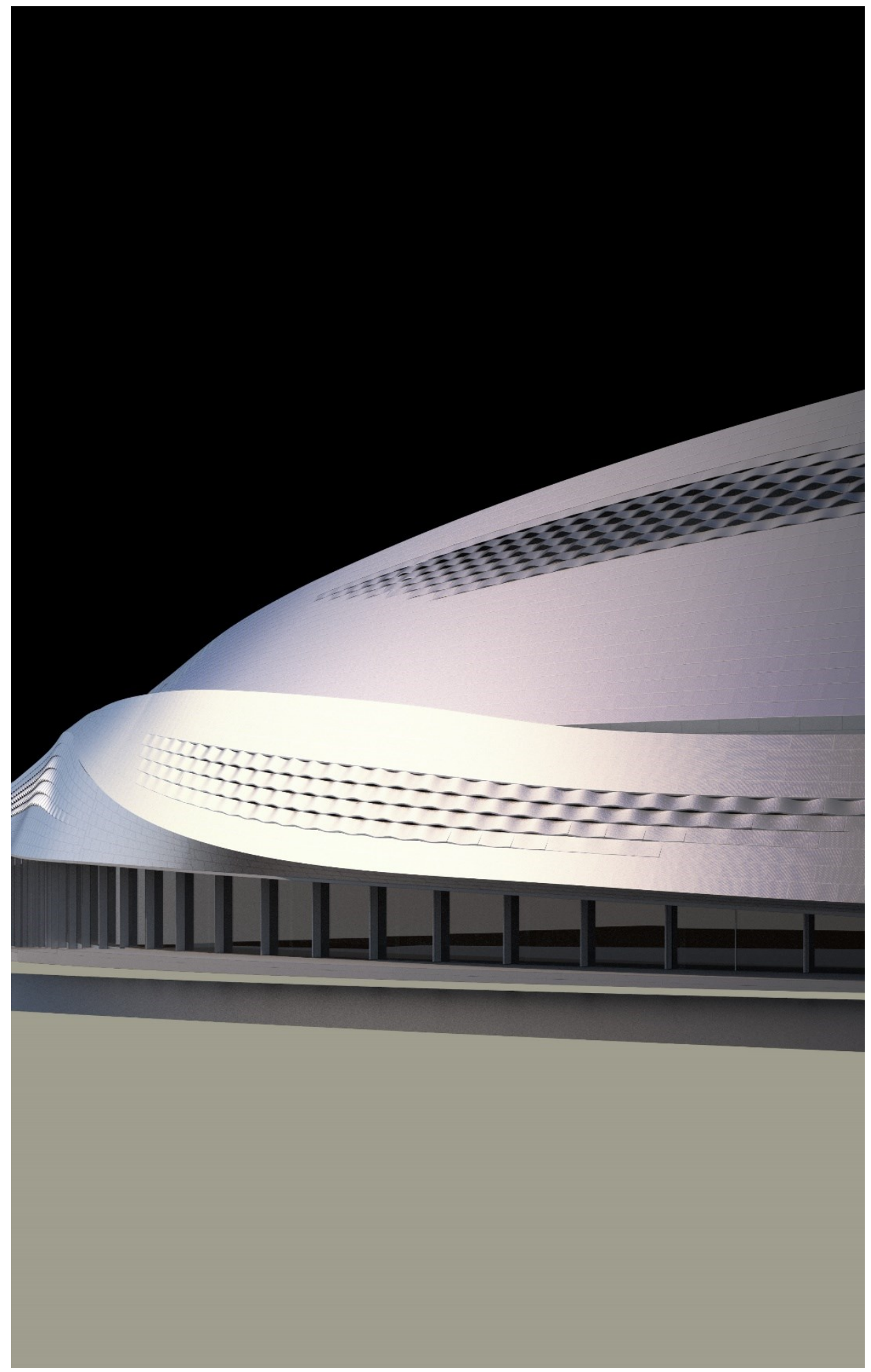

Figure 3.18: perspective showing the exterior surface, featuring a multiple-inlet system 


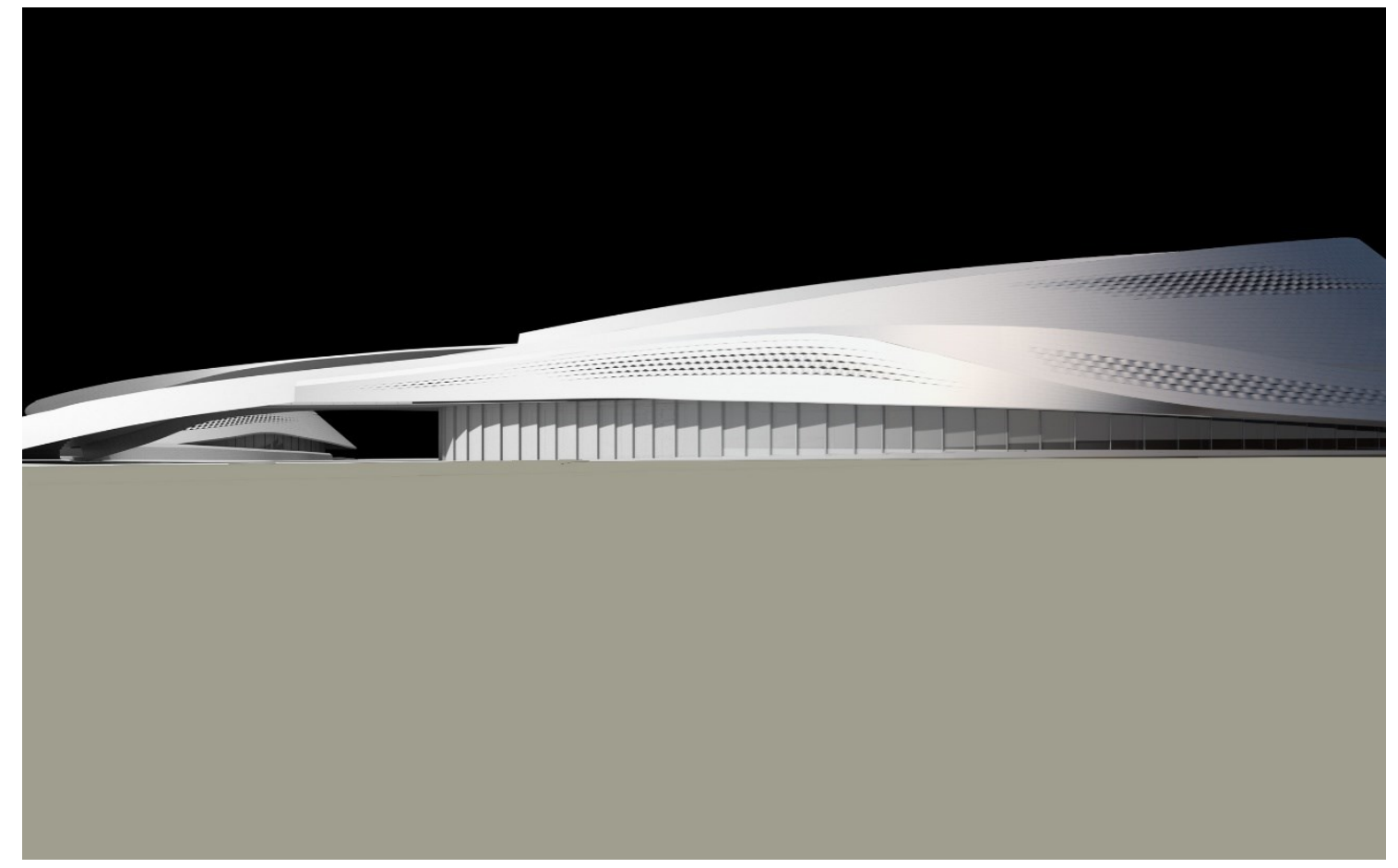

Figure 3.19: perspective showing the exterior surface, featuring a multiple-inlet system 


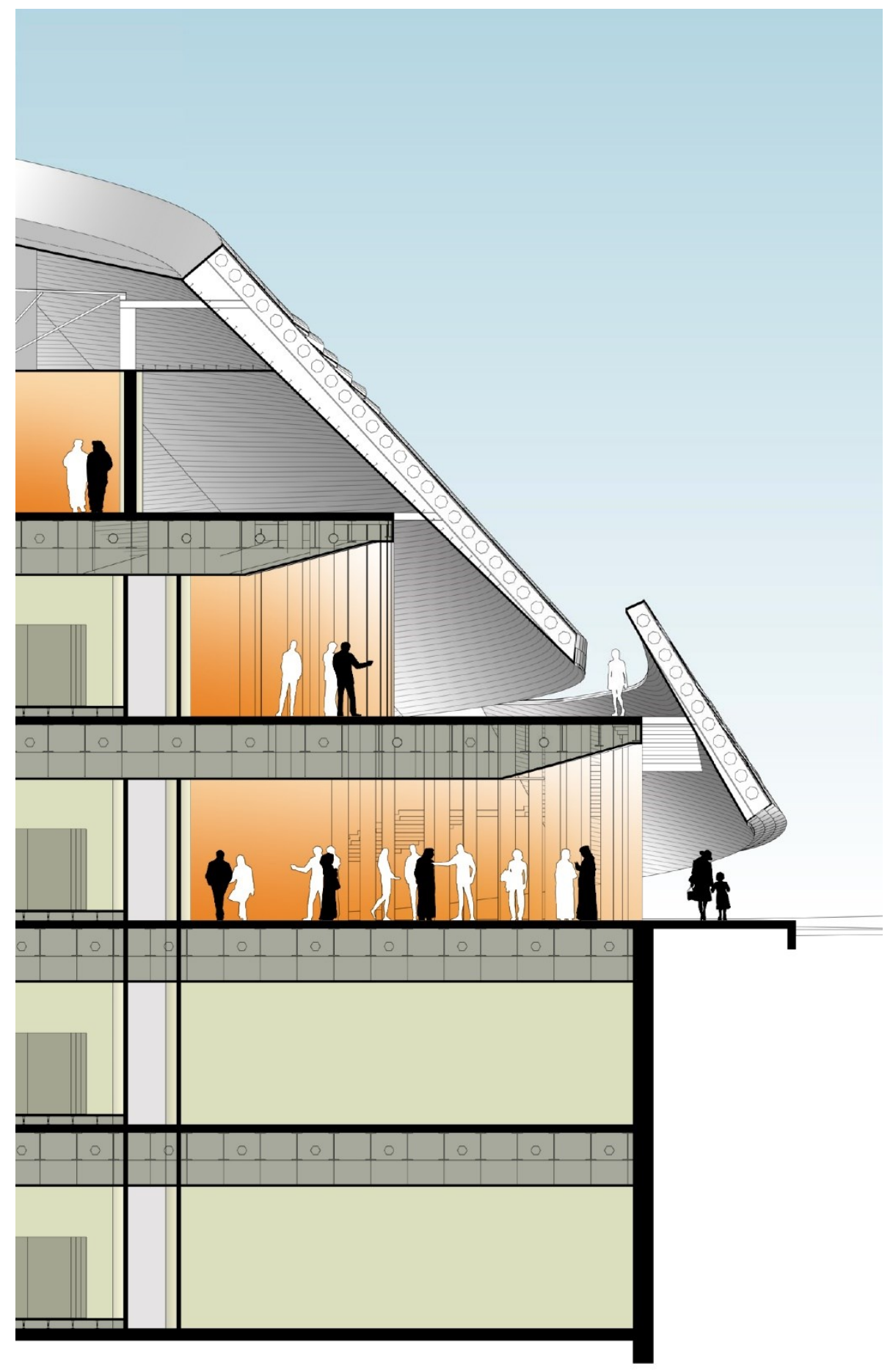

Figure 3.20: section showing the relationship between the exterior skin and the interior spaces 


\subsubsection{Estimating Electricity Generation Potential}

The total surface area of the proposed building envelope is $7900 \mathrm{~m}^{2}, 3500 \mathrm{~m}^{2}$ (roughly $50 \%$ ) of which is designed to incorporate photovoltaics. PVs are proposed to be located only on the southern and western surfaces, since they are exposed to the highest levels of solar irradiance (figure 3.19, portions coloured in orange and yellow). The curved envelope is rationalized with a faceted, rectangular pattern that can accommodate both rigid and flexible photovoltaic material; as illustrated in section 3.3.3, the faceted surface incorporates both flat and torqued panels, each requiring a different material. Roughly $1 \mathrm{~m}^{2}$ in surface area each, the panels are hypothetically rated at $1 \mathrm{~kW}$ per unit. According to NRCAN's photovoltaic potential and insolation dataset (table 3.4), the mean yearly energy production potential for each panel in Ottawa is $1198 \mathrm{kWh}$. Based on this figure, the system's total capacity is conservatively estimated to be $3.5 \mathrm{MW}$, capable of powering 388 single family homes annually (based on a consumption of 10,800kWh/yr per household). Comparatively, the nearby Chaudière Falls hydroelectric power plant has a capacity of $5 \mathrm{MW}$, although it produces a greater amount of electricity since it is operational $24 / 7$, as opposed to a photovoltaic installation that only produces power during daylight hours.

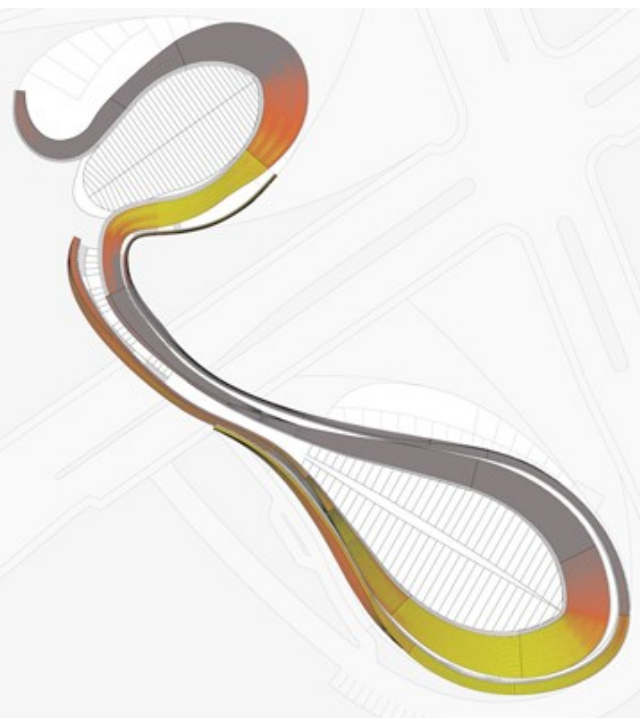

Figure 3.21: plan highlighting surfaces exposed to varying levels of irradiation, annually 


\begin{tabular}{|l|l|l|l|}
\hline Major Canadian Cities and Capitals & $\begin{array}{c}\text { Yearly PV } \\
\text { Potential } \\
(\mathrm{kWh} / \mathrm{kW})\end{array}$ & Major Cities Worldwide & $\begin{array}{l}\text { Yearly PV } \\
\text { Potential } \\
(\mathrm{kWh} / \mathrm{kW})\end{array}$ \\
\hline Regina (SK) & 1361 & Cairo, Egypt & 1635 \\
\hline Calgary (AB) & 1292 & Capetown, South Africa & 1538 \\
\hline Winnipeg (MB) & 1277 & New Delhi, India & 1523 \\
\hline Edmonton (AB) & 1245 & Los Angeles, U.S.A. & 1485 \\
\hline Ottawa (ON) & 1198 & Mexico City, Mexico & 1425 \\
\hline Montreal (QC) & 1185 & Regina, Canada & 1361 \\
\hline Toronto (ON) & 1161 & Sydney, Australia & 1343 \\
\hline Fredericton (NB) & 1145 & Rome, Italy & 1283 \\
\hline Quebec (QC) & 1134 & Rio de Janeiro, Brazil & 1253 \\
\hline Charlottetown (PE) & 1095 & Beijing, China & 1148 \\
\hline Yellowknife (NT) & 1094 & Washington, D.C., U.S.A. & 1133 \\
\hline Victoria (BC) & 1091 & Paris, France & 838 \\
\hline Halifax (NS) & 1074 & St. John's, Canada & 933 \\
\hline Iqaluit (NU) & 1059 & Tokyo, Japan & 885 \\
\hline Vancouver (BC) & 1009 & Berlin, Germany & 848 \\
\hline Whitehorse (YT) & 960 & Moscow, Russia & 803 \\
\hline St. John's (NL) & 933 & London, England & 728 \\
\hline
\end{tabular}

Source: National Resources Canada (2007). Photovoltaic potential and solar resources maps of Canada.

Table 3.4: Yearly PV Potential of Major Canadian Cities and Cities Worldwide

The effect of temperature on photovoltaic energy production is inextricably connected to the estimation of system potential, and by extension, the physical design of a BIPV envelope. A reference temperature of $25^{\circ} \mathrm{C}$ is typically used as a standard for solar PV module laboratory tests, and any change in temperature above or below this figure either increases or decreases the efficiency of a PV cell. The loss or increase in efficiency, defined as the temperature coefficient, is a number that can be determined by referring to manufacturers' product data, as each photovoltaic panel will be unique. For example, if a $150 \mathrm{~W}$ panel has a temperature coefficient of $-0.40 \% /{ }^{\circ} \mathrm{C}$, operation at $40^{\circ} \mathrm{C}$ would result in an output reduction of $9 \%$. On the other hand, output is increased in temperatures below $25^{\circ} \mathrm{C}$ (positive coefficient value). This is why BIPV applications in cold climates is desirable, since the added efficiency helps offset the reduced production due to fewer sunlight hours during winter months. 


\section{Conclusions and Recommendations}

This research has explored how photovoltaic technology can be integrated within a building envelope in order to generate power while simultaneously enhancing the spatial, aesthetic, and functional qualities of a project of architecture. The design for a BIPV façade presented as part of this research demonstrates how a practical technology can be adapted and integrated critically and creatively in order to address new and age-old challenges related to issues of human comfort and sustainability- the result of a rigorous design process.

The site selection for the project catered to the functional requirements of photovoltaic technology, informing the choice of a data centre as the primary building program. This lent itself to a highly fluid and flexible design process, maximizing the potential for the envelope to become an engaging building element in its own right. The resulting design integrates utility and community space within a single footprint, responding to site-specific conditions as well as the geometry of the envelope. While not designed as a solar farm, the capacity of the proposed PV system is comparable to that of a small hydroelectric power plant, proving how BIPV applications at a certain scale are functionally feasible. Consequently, its formal expression is symbolic of the age of sustainable development and information technology within which it has been designed, contributing to a visual history and culture that is in its early years of evolution. 


\subsection{Technical Challenges}

Despite its potential to meaningfully inform the design of a building, photovoltaic technology is itself the most significant limitation to any building integrated application. The method of manufacturing individual crystalline cells, for example, is limited by the chamfered square form of the ingot that has to be sliced into usable wafers. This influences the design of panels since it is more space-efficient to use square forms as opposed to any other geometry; using a triangular shape represents a loss in surface area that could otherwise be used for additional cells, consequently producing more electricity.

Site constraints have the greatest potential to influence the integration of photovoltaics on any given building, particularly those located in urban areas where access to sunlight is restricted, or those located in areas with challenging climates. This research did not investigate the potential structural issues associated with freeze-thaw cycles in the Canadian climate, where the project is speculatively located. Ice build-up, melt, and refreeze on exterior surfaces affect the feasibility of any proposed geometry for both individual panels as well as the overall form; in the case of this research, these panels are assumed to be smooth. Testing various geometries for panels, perforations, louvres, and vents is required in order to further develop the potential for such an application to perform as intended, under real world conditions.

\subsection{Design Challenges}

As is the case with most unconventional and novel designs, trade-offs will have to be made in terms of balancing marketable sales features with the sometimes unmarketable sustainable features of a building. An office tenant may be unwilling to sacrifice even the most compromised views for the sake of lower utility bills, despite increasingly expensive electricity prices, which may well strengthen the argument for BIPV applications; the potential purchaser of a condominium dwelling may be equally unwilling to sacrifice views,

unless the design of a BIPV façade enhances the privacy of the space or its spatial quality, as demonstrated in the project presented in section 3. 
Integrating photovoltaic technologies within buildings is not necessarily formulaic or straightforward. Depending on the type of building (commercial, residential, institutional, etc.), locating photovoltaic panels on non-optimal surfaces- at non-optimal tilt and rotation angles- can in fact be more energy efficient than PV applications designed strictly to capture the maximum amount of irradiation. For example, a residential building that undergoes peak operations early in the morning and late in the afternoon can be more efficient with BIPV applications on its east and west façades, despite lower levels of total annual irradiation. During peak levels of irradiation at mid-day, south facing panels will overproduce and therefore waste energy, unless it is stored for later use. Even so, the storage of excess power is often prohibitively expensive and impractical due to battery systems' relative inefficiency, not to mention the cost associated with constructing physical space to store them. Applications of photovoltaic technology within such typologies will result in characteristically different formal expressions than the one presented as part of this research, the result of another design approach altogether. This broadens the notion of what kind of aesthetic an 'architecture of solar energy' has, or ought to have.

\subsection{Sustainability}

However limitless a source of power, the materials and systems used for the capture of solar energy are themselves not yet renewable; the embodied energy associated with their design and production is high. Until these components are made to be renewable, solar energy's classification as a sustainable source of power remains challenged and requires further development.

At the moment the majority of BIPV and PV applications within buildings are crude and can sometimes present challenges at the municipal level in terms of rezoning and development approvals; government officials and local residents often have an adverse reaction to the aesthetics of such installations. As the incorporation of renewable energy technologies such as photovoltaics become more common within buildings, researchers, manufacturers, service providers, and fabricators will take solar technology more seriously 
as a proper building material, catalyzing further technological development in the area and eventually overcoming such barriers, entering into mainstream application. 


\section{Bibliography}

ASHRAE, 2009, -ASHRAE Handbook of Fundamentals, American Society of Heating, Refrigerating and Air-Conditioning Engineers, Atlanta, GA, USA

Agathokleous, Rafaela A., and Soteris A. Kalogirou. "Double Skin Facades (DSF) and Building Integrated Photovoltaics (BIPV): A Review of Configurations and Heat Transfer Characteristics." Renewable Energy 89 (2016): 743-56. Web.

Chen, Yuxiang, A.k. Athienitis, and Khaled Galal. "Modeling, Design and Thermal Performance of a BIPV/T System Thermally Coupled with a Ventilated Concrete Slab in a Low Energy Solar House: Part 1, BIPV/T System and House Energy Concept." Solar Energy 84.11 (2010): 1892-907. Web.

Chen, Yuxiang, Khaled Galal, and A.k. Athienitis. "Modeling, Design and Thermal Performance of a BIPV/T System Thermally Coupled with a Ventilated Concrete Slab in a Low Energy Solar House: Part 2, Ventilated Concrete Slab." Solar Energy 84.11 (2010): 1908-919. Web.

Clark, Woodrow W., and Grant Cooke. Global energy innovation: why America must lead. Santa Barbara, CA: Praeger, 2012. Print.

Dehghani-Sanij, A.r., M. Soltani, and K. Raahemifar. "A New Design of Wind Tower for Passive Ventilation in Buildings to Reduce Energy Consumption in Windy Regions." Renewable and Sustainable Energy Reviews 42 (2015): 182-95. Web.

Harrison, Jim. Data Centres: An Introduction to Concepts and Design. N.p.: n.p., 2012. Print.

Harris, John. "Consumerism." International Social Work 47.4 (2004): 533-42. Web.

Hu, Jianhui, Wujun Chen, Deqing Yang, Bing Zhao, Hao Song, and Binbin Ge. "Energy Performance of ETFE Cushion Roof Integrated Photovoltaic/thermal System on Hot and Cold Days." Applied Energy 173 (2016): 40-51. Web.

Hu, Jianhui, Wujun Chen, Qiyao Cai, Chengjun Gao, Bing Zhao, Zhenyu Qiu, and Yegao Qu. "Structural Behavior of the PV-ETFE Cushion Roof." Thin-Walled Structures 101 (2016): 169-80. Web. 
Hu, Jianhui, Wujun Chen, Bing Zhao, and Hao Song. "Experimental Studies on Summer Performance and Feasibility of a BIPV/T Ethylene Tetrafluoroethylene (ETFE) Cushion Structure System." Energy and Buildings 69 (2014): 394-406. Web.

Jonathan Stoller. "Why cold Canada is becoming a hot spot for data centres." The Globe and Mail. Special to Globe and Mail Update, corrected, 2013. Web. 20 Sep. 2016.

Kemery, Briana Page, Ian Beausoileil-Morrison, and Ian H. Rowlands. eSim 2012: The Canadian Conference on Building Simulation. May 1-4, 2012, Dalhousie University, Halifax, Nova Scotia, Canada.

Lin, Ching-Fuh, Su, Wei-Fang, Wu, Chih-I, Cheng, and I-Chun. Organic, Inorganic and Hybrid Solar Cells. N.p.: John Wiley \& Sons, 2012. Print.

Picon, Antoine. Ornament: the Politics of Architecture and Subjectivity. Somerset: Wiley, 2014.

Print.

Pizzini, Sergio. Advanced silicon materials for photovoltaic applications. Chichester: John Wiley \& Sons, 2012. Print.

Randall, Julian. Designing Indoor Solar Products. N.p.: John Wiley \& Sons, 2005. Print.

The Globe and Mail. "A telecom nerve centre to a nation." The Globe and Mail. The Globe and Mail, 2012. Web. 20 Sep. 2016.

"Data Centre Consolidation." Government of Canada, Shared Services Canada. N.p., n.d. Web. 20 Sep. 2016.

"Data centre design and engineering - Toronto and Montreal examples." Canadian Consulting Engineer. N.p., n.d. Web. 20 Sep. 2016.

"Data Centres Canada - Mississauga - TeraGo Networks." TeraGo. N.p., n.d. Web. 20 Sep. 2016.

"Downtown Toronto Data Centre features." UDCS. N.p., n.d. Web. 20 Sep. 2016.

"How many BTUs are equivalent to 1 ton of cooling capacity?" Reference. N.p., n.d. Web. 20 Sep. 2016.

"Low to High Density Cooling - A Flexible Data Centre Solution." Low to High Density Cooling - A Flexible Data Centre Solution / BladeRoom.com. N.p., n.d. Web. 20 Sep. 2016.

"Toronto Colocation Provider." Toronto Data Centers / Premium Toronto Colocation by Equinix.

Yang, Tingting, and Andreas K. Athienitis. "Performance Evaluation of Air-based Building Integrated Photovoltaic/Thermal (BIPV/T) System with Multiple Inlets in a Cold Climate." Procedia Engineering 121 (2015): 2060-067. Web.

Youssef, Amr M. A., Zhiqiang John Zhai, and Rabee M. Reffat. "Design of Optimal Building Envelopes with Integrated Photovoltaics." Build. Simul. Building Simulation 8.3 (2015): 353-66. Web. 
Urbanetz, Jair, Clarissa Debiazi Zomer, and Ricardo Rüther. "Compromises between Form and Function in Grid-connected, Building-integrated Photovoltaics (BIPV) at Low-latitude Sites." Building and Environment 46.10 (2011): 2107-113. Web. 